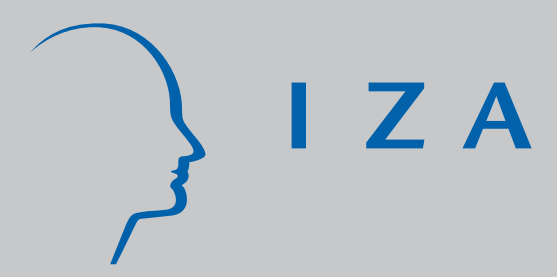

IZA DP No. 5890

Substitution Between Individual and Cultural Capital: Pre-Migration Labor Supply, Culture and US Labor Market Outcomes Among Immigrant Woman

Francine D. Blau

Lawrence M. Kahn

July 2011 


\title{
Substitution Between Individual and Cultural Capital: Pre-Migration Labor Supply, Culture and US Labor Market Outcomes Among Immigrant Woman
}

\author{
Francine D. Blau \\ Cornell University, \\ NBER, CESifo and IZA \\ Lawrence M. Kahn \\ Cornell University, \\ CESifo, NCER (Australia) and IZA
}

Discussion Paper No. 5890

July 2011

IZA

P.O. Box 7240

53072 Bonn

Germany

Phone: +49-228-3894-0

Fax: +49-228-3894-180

E-mail: iza@iza.org

\begin{abstract}
Any opinions expressed here are those of the author(s) and not those of IZA. Research published in this series may include views on policy, but the institute itself takes no institutional policy positions.

The Institute for the Study of Labor (IZA) in Bonn is a local and virtual international research center and a place of communication between science, politics and business. IZA is an independent nonprofit organization supported by Deutsche Post Foundation. The center is associated with the University of Bonn and offers a stimulating research environment through its international network, workshops and conferences, data service, project support, research visits and doctoral program. IZA engages in (i) original and internationally competitive research in all fields of labor economics, (ii) development of policy concepts, and (iii) dissemination of research results and concepts to the interested public.
\end{abstract}

IZA Discussion Papers often represent preliminary work and are circulated to encourage discussion. Citation of such a paper should account for its provisional character. A revised version may be available directly from the author. 


\section{ABSTRACT \\ Substitution Between Individual and Cultural Capital: Pre-Migration Labor Supply, Culture and US Labor Market Outcomes Among Immigrant Woman*}

In this paper we use New Immigrant Survey data to investigate the impact of immigrant women's own labor supply prior to migrating and female labor supply in their source country to provide evidence on the role of human capital and culture in affecting their labor supply and wages in the United States. We find, as expected, that women who migrate from countries with relatively high levels of female labor supply work more in the United States. Moreover, most of this effect remains when we further control for each woman's own labor supply prior to migrating, which itself also strongly affects labor supply in the United States. Importantly, we find a significantly negative interaction between pre-migration labor supply and source country female labor supply. We obtain broadly similar effects analyzing the determinants of hourly earnings among the employed in the United States, although the results are not always significant. These results suggest an important role for culture and norms in affecting immigrant women's labor supply, since the effect of source country female labor supply on immigrant women's US work hours is still strong even controlling for the immigrant's own pre-migration labor supply. The negative interaction effects between previous work experience and source country female labor supply on women's US work hours and wages suggest that cultural capital and individual job-related human capital act as substitutes in affecting preparedness for work in the US.

JEL Classification: J16, J22, J24, J61

Keywords: $\quad$ gender, immigration, labor supply, human capital

Corresponding author:

Lawrence M. Kahn

Cornell University

258 Ives Hall

Ithaca, NY 14853

USA

E-mail: Imk12@cornell.edu

\footnotetext{
Preliminary draft. Comments welcome. The authors are grateful to participants at the ESOP Workshop on Gender and Households, University of Oslo, May 2011, for helpful comments, Peter Brummund for excellent research assistance, and Cornell University for financial support.
} 


\section{Introduction}

In recent decades, the share of the US population that was foreign-born has risen from $4.8 \%$ in 1970 to $11.1 \%$ in 2000 , with a further increase to $12.2 \%$ in 2009 (US Bureau of the Census web site: http://www.census.gov ). Perhaps more dramatically, the percentage of the foreign-born population that came from Europe or North America fell from 70.4 to $18.5 \%$ between 1970 and 2000, ${ }^{1}$ with a corresponding increase in the Asian and Latin American share from 28.3 to $78.2 \%$; by 2009, the combined Asian and Latin American share had risen further to 81.1\% (US Bureau of the Census web site: http://www.census.gov ).

As the share of US residents who were born abroad rises and as the regions from which immigrants arrive shift toward areas with different cultures and traditions from the largely European origins of the US-born population, economists are paying increasing attention to issues of culture and assimilation. Recent research has shown that immigrants increasingly come from countries with a more traditional division of labor by gender than exists among the US-born population (Blau, Kahn and Papps 2011). Moreover, several studies have found a positive correlation between indicators of female labor force activity in an immigrant or second generation woman's source country and her labor supply behavior in the United States (Antecol 2000; Fernández and Fogli 2009; Blau, Kahn and Papps 2011). Such findings are suggestive of cultural influences on female labor force behavior, particularly since the effects on immigrants persist with long duration in the United States (Blau, Kahn and Papps 2011) and influence the labor supply behavior of second and higher generation women (Fernández and Fogli 2009; Antecol 2000).

\footnotetext{
${ }^{1}$ The Census did not report data for the North America category separately in its 2009 report, so that we were not able to construct a combined European-North American share; however the share of immigrants from Europe fell from $59.7 \%$ in 1970 to $15.8 \%$ in 2000, and $12.4 \%$ by 2009 (US Bureau of the Census web site: http://www.census.gov ).
} 
In this paper, we take a closer look at the association between female labor force activity in the source country and immigrant woman's behavior in the United States to better understand the mechanisms through which the effect operates. For example, do immigrant women from high female labor supply source countries have more work experience prior to their arrival in the United States? If so, the observed effect of source country may be due at least in part to the relatively high levels of job-related human capital that they accumulated before migration. On the other hand, if there is a positive relationship between high source country female activity rates and immigrant women's US labor supply, even controlling for their pre-migration labor supply, then one may be more confident that labor market-oriented values or additional skills beyond those directly tied to employment have been transmitted to such women. In other words, it would provide evidence for an effect of broader culture or social capital in the relationship between source country participation rates and the US labor market behavior of immigrant women.

Evidence on these mechanisms could also yield important information about the likely impact of immigration policies on the labor force behavior of the women who migrate. For example, US policies regarding diversity visas have a direct effect on the distribution of countries from which immigrants arrive and therefore the cultural backgrounds of those migrants who are granted visas. ${ }^{2}$ Employment visas, on the other hand, are likely to be selective of those with previous work experience; thus, policies regarding the number of such visas may directly affect the prior work experience of immigrants as well as indirectly affecting the types of source countries they migrate from. Since immigration policies may have differing effects on the distribution of source countries and the pre-migration labor supply of migrant women, it is

\footnotetext{
2 The US Diversity Immigrant Visa Program creates 50,000 diversity visas each year, which are given by lottery to those from countries with low immigration rates to the United States. See http://travel.state.gov/visa/immigrants/types/types_1322.html .
} 
important to have information on the impact of both source country characteristics and actual pre-migration behavior on US labor supply.

In this paper, we use a rich new data set, the New Immigrant Survey, to investigate the separate effects of immigrant women's own labor supply prior to migrating and of their source country characteristics, and thus to provide new evidence on the role of human capital and culture in affecting immigrant women's labor supply in the United States. Our major contribution over previous research is that we are able to disentangle the effects of immigrants' own past behavior from that of the average behavior of women and men in their source country in affecting labor supply in the United States. ${ }^{3}$ Similar to previous work (Antecol 2000; Blau, Kahn and Papps 2011), we find that women who migrate from countries with relatively high levels of female labor supply work more in the United States. Of particular interest is that, using this unique data source, we are able to show that most of this effect remains when we further control for each woman's own labor supply prior to migrating, and, further, that immigrant women's pre-migration labor supply also strongly positively affects their labor supply in the United States. Finally, we find a significantly negative interaction between pre-migration labor supply and source country female labor supply. This means that the impact of source country female labor supply is stronger for those who did not themselves work for pay before migrating than among those with work experience in their source country, while the impact of premigration work experience is larger for those from source countries with low female labor supply than for those from high female labor supply countries. We obtain broadly similar results analyzing the determinants of hourly earnings among immigrant women who are employed in the United States, although the effects are not always significant.

These results suggest an important role for culture and norms in affecting immigrant women's labor supply, since the effect of source country female labor supply on immigrant

${ }^{3}$ As discussed in more detail below, this feature of our design is similar conceptually to Fernández and Fogli's (2006) analysis of the fertility of US-born women with different ethnic backgrounds. 
women's work hours in the United States is still strong even controlling for the immigrant's own pre-migration labor supply. The negative interaction effects between pre-migration work experience and source country female labor supply on immigrant women's US work hours and wages suggest that cultural capital can substitute for individual job-related human capital in affecting preparedness for work in the United States.

\section{Relationship to Previous Literature and Contribution of the Study}

Our analysis builds on some recent papers that have studied the impact of source country characteristics on the labor supply of immigrant women. For example, Antecol (2000) found, using the 1990 Census, that source country female labor force participation rates were positively correlated with the US labor force participation of immigrant women, even controlling for human capital characteristics. Blau, Kahn and Papps (2011) further elucidated the nature of this relationship by examining the impact of source country characteristics on immigrant women's labor supply assimilation profiles - the relationship between time in the United States and labor supply. They found that migrating from a country with higher female labor force participation permanently raised immigrant women's labor supply profile in the United States but did not influence its slope, which was strongly positive no matter what type of country they migrated from. Those who came from high female labor supply countries eventually assimilated fully to native labor supply levels, while there was a persistent $10-12 \%$ shortfall relative to comparable natives among those who migrated from a low female labor supply country. In addition, Blau's (1992) study, which found a positive effect of source country fertility rates on immigrant women's fertility, also suggests an impact of gender roles in source countries on the behavior of immigrant women in the United States.

Recent economic research has also studied the impact of source country characteristics on the behavior of US-born women descended from immigrants. For example, Antecol (2000) found a positive correlation between US and source country participation for "second and higher 
generation" immigrants, defined by their answer to the Census question on ancestry. Similarly, the labor supply and fertility behavior of US-born daughters of immigrants (the second generation) has been found to be positively associated with both female participation and fertility rates in their parents' country of origin (Fernández and Fogli 2009) and the participation and fertility patterns of immigrants from those origin countries (Blau, Kahn, Liu and Papps 2008). Moreover, in a study that examined the impact of culture on the fertility of US-born women from different ethnic backgrounds, Fernández and Fogli (2006) used General Social Survey (GSS) data from 1977-1987 to examine the determinants of fertility in analyses that included both the 1950 fertility rate of the respondent's self-reported country of ancestry and her number of siblings as explanatory variables. Their paper's design is conceptually similar to ours in that they had a control for both the fertility of the respondent's own parents (i.e., her number of siblings) and fertility in her country of ancestry. Both variables positively affected current fertility and, since the impact of the source country fertility level was still positive even controlling for the number of siblings, the results suggest an impact of culture beyond the behavior of one's own family.

These studies of the transmission of source country values and behavior among immigrants and their descendants are also relevant to a broader literature examining the impact of "culture," or preferences and beliefs developed in a different time or place on current economic behavior (Fernández 2008). While prior results relating immigrant women’s US labor supply to female labor force participation in their source countries suggest an impact of culture, they do not provide much insight into the possible mechanisms behind this relationship. The correlation could be partially or fully due to the effects of ethnic capital or culture. A woman growing up in a country where women are expected to work outside the home may acquire knowledge about how to succeed in the workplace, or a predilection for market work, regardless or whether or not she has been employed herself. Such knowledge might be transmitted through role models such as relatives or friends who have work experience. Thus, cultural capital as measured by female labor force activity in an immigrant's source country may be a source of job-related human capital that can be tapped upon migration to the United States. Alternatively, 
the correlation between source country female labor supply and immigrant women's labor supply in the United States might simply reflect the immigrant woman's own pre-migration behavior. This would be the case if, as is likely, women migrating from high female labor supply countries have accumulated higher levels of labor market experience prior to migrating. Such an association could not only influence their wages upon migrating to the United States, but also their attitudes about market work. Any association between pre-migration work experience and labor supply in the United States due to these factors may be magnified or reduced by selection: migrants from high female labor force participation source countries may be more or less positively selected on pre-migration labor supply/work-orientation than those from low female labor force participation source countries. Finally, the observed correlation between source country female labor supply and immigrant women's labor supply in the United States might be due to a combination of both factors: the impact of broader culture and prior work experience.

These hypotheses about the mechanisms through which the work orientation of women in a migrant's source country affect work behavior in the United States can be analyzed only if one has data on both individual migrants' source countries and their work behavior before and after migrating. If the impact of source country female labor supply remains positive and significant in models which control for immigrant women's pre-migration work experience, it suggests that culture or ethnic capital may have broader impacts beyond merely influencing women's premigration work behavior.

The data sets generally used to analyze immigrant behavior in the United States- the Census, the American Community Survey (ACS), and the Current Population Survey (CPS-since 1994) — contain information on immigrants and their source countries, but not on immigrants' work behavior prior to migrating. National origin country data sources, from which labor force behavior in source countries may be calculated, do not of course break out the behavior of residents from that of future migrants to the United States. Thus, in this paper, we study these issues using a relatively new data set, the New Immigrant Survey (NIS), which contains information not only on immigrants' source countries and labor supply behavior in the United States, but also on the labor supply and schooling they received before migrating. The 
NIS allows us to disentangle the effects of the migrant's own past behavior from that represented by source country characteristics. Because the NIS contains information on when the respondent left the source country, we can assign source country characteristics as of that date of migration, as in Blau, Kahn, and Papps (2011). In addition, unlike the Census, ACS or CPS, the NIS contains detailed information on visa type, allowing for a more extensive set of controls in studying immigrants' labor market outcomes.

\section{Data and Descriptive Patterns}

Our basic data source, the NIS, is a nationally-representative survey of 8573 adult immigrants who received admission to permanent legal residence in the United States in 2003 (Jasso, Massey, Rosenzweig and Smith forthcoming). ${ }^{4}$ The respondents were interviewed during 2003 or 2004 with about 2/3 of the sample surveyed in the earlier year. Some had just arrived in the United States with permanent residence visas already issued, while others were already in the United States, either under temporary visas or illegally. Although the NIS is not representative of all immigrants (because presumably some never become legalized), it does represent a random sample of those obtaining legal status in a given year. The NIS contains information on the respondent's country of birth and when the immigrant left his/her source country. We use this information to match source country characteristics from a time-series cross-section data base we constructed, as described in more detail below and in the Appendix. A key component of our design is that we are able to measure source country variables at the time one left that country. This is a potentially important feature of our analysis, since we would like to know the kinds of norms and values the respondent grew up with.

Our sample is restricted to individuals who migrated as adults (age 18 and over) and were currently no older than 65 . Focusing on adult immigrants is appropriate because we want to study the effects of source country culture on US behavior, and those who migrated at very

${ }^{4}$ A small fraction (about $0.5 \%$ ) were admitted during 2002. For additional information on the NIS, see: http://nis.princeton.edu/ . 
young ages may be very Americanized by the time they reach adulthood. Moreover, since we wish to examine the role of pre-migration labor market experience, we need a sample of individuals for whom this is a realistic possibility. We also exclude the small number of new immigrants who were not currently living in the United States (about 1.2\% of the sample), although the results were virtually identical including them. The NIS supplied a set of sampling weights, which we use in all of our analyses, thereby assuring that we have a representative sample of newly legalized immigrants.

We now examine the characteristics of the NIS sample, which as noted contains information not available in other data bases on immigrants. Table 1 shows descriptive information for men and women overall as well as separately for three major source regions: South and East Asia; Latin America and the Caribbean; and Europe and Central Asia. Several conclusions about gender and employment before and after immigration emerge. First, overall, immigration seems selective of women with high relative work propensities. This can be seen by comparing the gender ratio for the average incidence of pre-migration employment among immigrants to the gender ratio for activity rates in the source country. ${ }^{5}$ Table 1 shows that before migration, women were $78 \%$ as likely as men to have worked for pay (i.e., $0.532 / 0.686 \approx 0.78$ ), while the average female/male activity rate ratio in migrants' source countries at the time they migrated was only $0.59-0.60 .^{6}$ Of course, in addition to selection, the higher female/male ratio in pre-migration employment propensity in the NIS compared to the source country average may also be due to the age or education composition of immigrants or to temporarily high labor supply among immigrant women earning money before leaving their source country to help finance their (and their family's) migration.

\footnotetext{
5 While the activity rates include unemployment, the NIS does not contain information on pre-migration unemployment.

${ }^{6}$ This average is implicitly a weighted average across source countries, where countries which send a lot of migrants to the United States will be more highly represented in the average.
} 
Second, in terms of the labor supply behavior of the specific women who do migrate, migration appears to widen the gender gap in employment or work hours. For example, 53.2\% of women worked before migrating, compared to only $46.8 \%$ after coming to the United States (a 6.4 percentage point decline, or about 12 percent of the pre-migration mean); for men, the share working rose from $68.6 \%$ before migration to $73.6 \%$ in the United States $(7.3$ percent relative to the mean). While average work hours (including those not working) fell for both men and women, they fell much more for women (306 hours, or 29.4\%) than for men (114 hours, or $7.5 \%) .^{7}$ Several interpretations of these changes in labor supply are possible. On the one hand, perhaps women are returning to their intended labor supply levels, which may have been temporarily inflated pre-migration in an attempt to help finance their move. Alternatively, it is possible that women's early labor supply in the US is temporarily reduced due to their having greater difficulty than men in locating employment or to the disruption of moving and the resulting disproportionately high level of family responsibilities for women under a traditional division of labor. Gender differences in visa types may also contribute to this result. The NIS data show that family visas are by far the most common method of attaining legal permanent resident status for both sexes, but were more common among women than men. Fully $62.5 \%$ of women compared to $47.6 \%$ of men had such visas. Not surprisingly, the reverse was true for employment visas, which were somewhat more common for men $(14.5 \%)$ than women $(10.1 \%)$.

In addition to these results for all immigrants, Table 1 shows some interesting patterns among the three major source regions represented in the NIS. Pre-migration labor supply among women is ranked similarly to the average source country female/male activity rate ratio: women worked on average 860 hours before migrating in Latin America and the Caribbean region, far less than they worked in South and East Asia (1128 hours) and in Europe and Central Asia (1368 hours)—regions with higher relative female activity ratios. Women's labor supply fell sharply

\footnotetext{
${ }^{7}$ Using the NIS data, Akresh (2008) found that women experience larger post-migration reductions in occupational prestige than men; a pattern that is similar to the labor supply comparisons we obtain here.
} 
after migration among Europeans and Asians but hardly changed for those migrating from Latin America and the Caribbean region. The gender gap in US labor supply was smaller both absolutely and relatively for Europeans and Central Asians than for those migrating from the other regions. Finally, the gender pay gap was about $0.20 \log$ points for those from Latin America and the Caribbean area and about $0.30 \log$ points for those from the other two regions.

Gender differences in the level of pre-migration schooling also differed by region. Men and women from Europe and Central Asia had about the same level of pre-migration schooling (14.1 years), while men's pre-migration schooling was somewhat higher than women's among those moving from Latin America and the Caribbean area (10.5 vs. 10.1 years) and considerably higher than women's for those migrating from South and East Asia (13.8 vs. 12.6 years). There were also some differences by visa type across the regions. The gender gap in employment visas was particularly large among those migrating from South and East Asia (20.3\% for women and $33.1 \%$ for men). Legalization visas were especially common among those migrating from Latin America and the Caribbean area (13.8\% for women and $19.3 \%$ for men), and diversity or refugee visas were more common among Europeans and Central Asians (42.1\% for women and 46.5\% for men) than for the other groups. The higher incidence of employment visas among those from Asia may reflect their longer distance of migration, a fixed cost that requires a larger labor market return to migration to offset (Chiswick 1978). Moreover, the higher incidence of legalization visas among those from Latin America likely reflects their relative ease of illegal border crossings, given their physical proximity to the United States, raising the stock of those potentially requesting such visas.

Table 1 Panel B shows means for the source country characteristics in the aggregate and separately by region. The source countries are implicitly weighted by the (weighted) number of immigrants from each country. Not surprisingly, the Europe and Central Asia region has higher levels of income, lower fertility, higher female activity rates, and higher schooling levels than the 
other two regions. In contrast, the Latin America and Caribbean region has relatively high fertility, low income, low education and low female supply. The international contrasts on these dimensions at the source-country level provide a source of cultural variation among immigrants that we will use in our empirical analyses.

Since the NIS sample includes only legalized immigrants, it may not be representative of all immigrants, because a large share of immigrants is believed to be undocumented. For example, the Department of Homeland Security estimated that as of January 2006, 39.6\% of the US foreign-born population was unauthorized (Hoefer, Rytina and Campbell 2007, p. 3). While it is impossible to fully ascertain the characteristics of the undocumented, it is instructive to compare the NIS data to US Census and ACS data, which contain information on both documented and undocumented immigrants, albeit in unknown proportions. ${ }^{8}$ Appendix Table A1 shows information from the 2000 US Census and 2005 ACS on similar variables (when available) for foreign-born individuals who arrived in the United States in the last 5 years (about $69 \%$ of the NIS sample arrived during the previous 5 years).

Several interesting contrasts and similarities emerge between the NIS and the samples collected by the Census Bureau data sets. First, the NIS sample is older than the immigrant respondents in the Census or the ACS - mean age was 38 for the NIS compared to 32-34 for the Census and ACS. This difference is consistent with the inclusion of unauthorized immigrants in the Census and ACS sample, since it is likely that it takes a significant amount of time for an undocumented immigrant to obtain permanent resident status.

Second, the NIS respondents are more highly educated than those in the Census or ACS: total years of schooling average 13.2 for men and 12.3 for women in the NIS, compared to 11.8 12.3 in the Census and ACS. ${ }^{9}$ It is likely that the sample of NIS respondents contains a

\footnotetext{
${ }^{8}$ In addition, illegal immigrants may be underrepresented in these data sets.

9 Because the Census and ACS code education in categories, we use Jaeger's (1997) suggested algorithm to convert these to years of schooling.
} 
disproportionate share of those with work qualifications and therefore higher schooling levels. Moreover, there is a gender gap in education favoring men in the NIS, while, in the Census and ACS, women have slightly higher levels of schooling. This pattern is consistent with those entering with work visas being disproportionately male (as we have seen is the case) and undocumented immigrants being disproportionately comprised of less educated men. This latter interpretation is also supported by the pattern showing larger shares of immigrants from Latin America and the Caribbean area in the Census and ACS than in the NIS. In addition, taking into account sampling weights, the 2000 Census and 2005 ACS samples consist of $52.1-52.5 \%$ men, in contrast to the NIS's $42.5 \%$ figure. Again, a higher level of illegal immigration among men is suggested.

Finally, despite these differences in demography and education, the gender gaps in work behavior and wages are very similar in the NIS to the Census and ACS. In the NIS, men work an average of 1399 hours (including those with zero work hours), compared to 1436-1634 in the Census and ACS; women in the NIS work 735 hours, compared to 764-826 hours in the Census and ACS. (Other measures of labor supply show also show comparable levels in the NIS and the other data sets.) And, the gender pay gap is roughly 0.20 log points in the NIS, compared to 0.14-0.16 in the Census and ACS. ${ }^{10}$ Thus, overall, for the purposes of analyzing work behavior, the NIS seems fairly representative of all immigrants, despite its limitation to those with permanent resident status.

\section{Empirical Procedures and Regression Results}

\footnotetext{
${ }^{10}$ The NIS provides information on the respondent's rate of pay and the time unit upon which this is based (i.e., hourly, weekly, bi-weekly, monthly, or annually). Combined with information on weeks worked in the last year and usual work hours, we can compute an hourly earnings measure. The NIS also has information on labor income in the last year. However, since there are more missing values for this variable than for the rate of pay on one's job, we use the latter in our wage analyses. As explained in the footnote to Table A1, we compute average hourly earnings in the Census and ACS using annual wage and salary income divided by annual work hours for wage and salary workers.
} 


\section{A. Empirical Procedures}

We analyze labor supply in the United States for a sample of women who migrated after age 17 and who were 65 years old or younger by estimating the following equation for immigrant $\mathrm{i}$, migrating from source country $\mathrm{c}$ at time $\mathrm{t}$ :

$$
\mathrm{H}_{\mathrm{ict}}=\mathrm{F}\left(\mathrm{X}_{\mathrm{i}}, \mathrm{Z}_{\mathrm{ct}}, \mathbf{u}_{\mathrm{i}}\right) \quad(\mathbf{1}),
$$

where:

$\mathrm{H}$ is annual hours worked in the United States, including zeroes; $\mathrm{X}$ is a vector of personal characteristics; $\mathrm{Z}$ is a vector of source country characteristics measured at the time of migration; and $\mathrm{u}$ is a disturbance term. We estimate (1) as a linear regression, although implementing a Tobit analysis to take account of the mass of points at zero hours led to very similar results. Standard errors were clustered at the source country level, allowing for a correlation across respondents from the same country regardless of the time of arrival.

$\mathrm{X}$ includes current age; age squared; a dummy for married spouse present; years of schooling completed before migrating; years since migrating to the United States (ysm); ysm squared; a series of race/ethnicity dummy variables including: Hispanic, Asian Nonhispanic, Black Nonhispanic, and Other Nonwhite Nonhispanic; and annual work hours before migrating, including zeroes. The source country characteristics (measured at the time of arrival) include female/male activity rate ratio; completed fertility; GDP in 1995 US dollars; gender-specific primary and secondary enrollment rates; distance to the United States; and dummies for Englishspeaking and for English-official but not English speaking countries. The construction of these variables is described in detail in the Appendix.

The personal characteristics variables are intended to measure preparedness for the US labor market, labor supply propensities and job opportunities. Age, schooling, and ethnicity may be proxies for human capital, the quality of schooling, or discrimination. Labor supply before migration and marital status may also reflect human capital as well, or labor supply propensity 
given human capital levels. The years since migration variable likely combines both true assimilation as well as cohort effects. Since the NIS consists of one cross-section, it is not possible to disentangle these using Borjas' (1985) suggested use of multiple cross-sections or Lubotsky's (2007) longitudinal data approach. Nonetheless, years since migration is a potentially important control, since as noted earlier, about $31 \%$ of immigrants who obtained legal permanent resident status arrived more than five years before the NIS survey.

Source country variables were selected to serve as indicators of the degree to which the source country has a traditional division of labor by gender and the extent of labor market preparedness of men and women from that country, and also to address possible issues of selective migration. Female relative labor supply and fertility rates in the source country are indicators of traditional gender roles in the country of origin which may, or may not, be replicated in the United States. Note that the measure of source country female labor supply we employ is women's labor force participation relative to men's (female LFP/male LFP). This relative measure is appropriate in that it captures the gender division of labor explicitly. A further advantage is that it implicitly adjusts for any problems in measuring the labor force, particularly at different levels of economic development, at least to the extent that such problems affect men's and women's measured participation rates similarly. Moreover, both source country female relative labor supply and fertility, as well as income, education, and use of English are all likely to be related to preparedness for work in the US labor market. In addition, migration likely involves a disruption of work patterns due to housing and job search in the United States. Those who came a long distance may suffer the largest disruption, likely negatively affecting their labor supply on arrival in the US. On the other hand, as discussed, because of the fixed costs of migration, those who choose to come from a greater distance are likely to have higher labor market returns to migration than those coming from shorter distances, 
all else equal (Chiswick 1978). Therefore, distance could be positively or negatively associated with labor supply in the United States.

Since we have controlled for actual work behavior and schooling before migrating, the source country variables can be interpreted as indicators of culture or community-level effects on the US labor supply of immigrant women. Moreover, an important test we implement is to interact the respondent's pre-migration labor supply with the female relative activity rate. The sign of this interaction effect will provide evidence on the degree to which actual work experience prior to immigration and source country female work propensity act as substitutes or complements in affecting preparedness or desire for work in the United States. On the one hand, it is possible that growing up in a country where women expect to work or observe others who work outside the home can provide skills which substitute for actual pre-migration work experience, producing a negative interaction effect. On the other hand, growing up in such a country may enhance the skills one has learned on the job, producing a positive interaction effect.

We note that the explanatory variables in equation (1) can affect immigrant women's labor supply directly as well as indirectly through their effects on wage offers in the United States. Thus, equation (1) should be seen as a reduced form. For example, source country female relative activity rates may, as suggested above, enhance immigrant women's human capital and affect their wage offers, which in turn will affect labor supply in the United States. In addition, even controlling for wage offers, cultural capital can affect women's desires for working in the United States, in effect shifting their labor supply function to the right. Below, we also examine the determinants of wage offers in the United States and make inferences about these direct and indirect effects of cultural capital on immigrant women's labor supply.

In addition to the basic model outlined above, we also estimate some supplementary specifications to test the robustness or sharpen our interpretation of the basic results. First, we 
estimate the basic models for men. Such analyses may be of interest in and of themselves and also provide a useful check on our interpretations. For example, suppose we find that the source country female relative activity rate is positively related to female labor supply in the United States. While this effect may be due to the impact of culture and gender-related norms, it may also be due to unobserved factors correlated with overall preparedness for work in the United States. Obtaining similar results for men would support the latter interpretation; however, if such a variable only affects women, then it likely would reflect gender-related norms.

Second, research on the assimilation of immigrants has acknowledged the potential problem of selective return migration. Specifically, in a sample of immigrants, we only observe those who have decided to stay, and their labor market experience may not be representative of the full population of individuals who have ever migrated. For example Lubotsky (2007) finds evidence that the stayers are positively selected. The immigrants in the NIS sample are mostly recent arrivals, so the problem of selective return migration may be less severe than in, for example, the Census, ACS or CPS, which contain many immigrants who have been in the United States for many years. Nonetheless, even recent immigrants may be planning return migration, and these plans, while possibly endogenous with respect to source country labor supply and past work behavior, may influence immigrant women's employment in the United States.

We address the issue of the possible selection bias due to return migration by using available data on emigration rates by source country (see the Data Appendix). Specifically, we include the female 1980-1990 emigration rate for immigrant women from the respondent's source country in some supplementary labor supply models. Adding this variable at least partially controls for differences across respondents in their plans to emigrate. However, since these plans themselves are likely to be affected by the respondent's own work history and cultural capital, our basic models are estimated without including the emigration rate. 
Third, in some models we include controls for the type of visa the respondent has obtained in achieving permanent resident status, a variable not available in other data sources. These include family visas, employment visas, diversity visas, refugee visas and legalization visas (e.g., those given during amnesties to people who were previously undocumented), with the omitted category being unspecified visa type. While visa type is likely endogenous with respect to skills and labor supply intentions, it may be useful to control for it in order to sharpen the interpretation of the underlying labor supply and source country characteristics variables.

Fourth, we additionally include dummies referring to the region in which the respondent was born and an indicator for the respondent's current religious tradition in some labor supply models. The regions include Africa, East and South Asia, Latin America, Europe-Central Asia, and North America-Oceania, with the latter group omitted. While the NIS data are not fine enough to permit individual source country dummies to be included, by adding regional controls in some models, we are able to sharpen the interpretation of the source country characteristics. Religious tradition takes on nine possible values, referring to: Catholic, Orthodox Christian, Protestant, Muslim, Jewish, Buddhist, Hindu, Other Religion, and No Religion (the omitted category). Controlling for the respondent's religion allows us to study the possible mechanisms through which source country culture can affect work behavior in the United States.

Fifth, in some models we control for education acquired in the United States and number of children ever born, again likely endogenous variables whose inclusion may reveal information about the effects of past labor supply and source country characteristics. ${ }^{11}$ Finally, we experimented with alternative forms of the dependent variable and found similar results to those reported here. Specifically, we estimated models with current employment or labor force participation as the dependent variable.

\footnotetext{
${ }^{11}$ One might argue that marital status is similarly endogenous, and we also estimate some models excluding marital status.
} 
In addition to analyzing labor supply, we also study the determinants of hourly earnings among immigrant women who were wage and salary workers. We are particularly interested in the impact of pre-migration labor supply and source country culture/norms on the labor market opportunities facing immigrant women, as indicated by wage offers. We use a sample of wage and salary workers who are not currently enrolled in school and a similar specification of explanatory variables to that in the labor supply models, augmented by years of schooling obtained in the United States. This specification allows us to compare the value of schooling obtained before and after migration. In estimating the wage equations, we need to confront the issue of sample selection, since, as Table 1 shows, only about $41 \%$ of immigrant women in the NIS were currently employed. We take two approaches to the issue of selection. First we assume that the wage offers of the nonemployed are similar to those of the employed who work only part of the year and predict log wages for the nonemployed using coefficients from a log wage regression estimated for those with low weeks worked. ${ }^{12}$ We may then include all respondents in the wage analysis by giving each woman her actual or predicted wage. Second, we perform a traditional selectivity bias correction analysis (Heckman 1979). In addition to functional form, the model is identified by including number of children, a variable that is excluded from the second stage (log wage) equation, in the first stage (probability of having a wage observation). We note that, since less than half of the sample is employed, we cannot use median regression methods to account for selection bias, as in Neal and Johnson (1996), Neal (2004), and Blau and Kahn (2006).

\section{B. Basic Regression Results}

Table 2 contains regression results for the determinants of annual work hours in the United States for immigrant women. We show several specifications, as indicated in our

\footnotetext{
${ }^{12}$ This method of estimating wages for the nonemployed has been used by Juhn (1992), Juhn and Murphy (1997), and Blau and Kahn (2007), among others.
} 
previous discussion. The first column shows the simplest specification, with only individual characteristics included, excluding visa type. Work hours before migrating have a positive, highly significant effect on work hours in the US. The coefficient is 0.101 , implying that a woman who worked the average number of hours among those who were employed prior to migrating (approximately 2000) will work roughly 202 hours (or about $27 \%$ of the immigrant unconditional mean work hours) more than a woman who did not work before migrating to the United States. Column 2 shows that this effect remains the same when we add source country characteristics other than female relative activity rate.

Column 3 shows the reduced form effect of the female relative activity rate obtained by excluding the respondent's own work hours prior to migration. The effect is 982 hours and is highly statistically significant. To gauge the magnitude of this effect, we note that the $75^{\text {th }}$ percentile of the female relative activity rate in our sample is .7045 (roughly the level in SubSaharan Africa) and the $25^{\text {th }}$ percentile is .4726 (roughly the level in the Dominican Republic). ${ }^{13}$ The estimate in column 3 implies that an increase from the $25^{\text {th }}$ to the $75^{\text {th }}$ percentile in the female relative activity rate will raise women's work hours by 228 hours ( $31 \%$ of the mean). ${ }^{14}$

Columns 4-6 of Table 2 explore the interplay between source country culture (the female/male activity rate ratio) and actual pre-migration labor supply in affecting immigrant women's work behavior in the United States. First, column 4 shows that adding the respondent's annual pre-migration work hours variable to the model reduces the effect of the source country female/male activity rate ratio by about 99 hours to a still highly significant value of 883 . Thus about $90 \%(883 / 982)$ of the total effect of source country culture remains even after we control for the immigrant's actual labor supply before migrating. And the effect of the respondent's premigration labor supply remains unchanged at .1. This latter result is interesting, partly because

13 These percentiles are based on individual observations (with sampling weights), which means that countries with a large number of observations, such as Mexico, will get greater weight in computing the percentiles.

${ }^{14}$ This is larger than the $12 \%$ figure obtained for newly arrived married immigrant women by Blau, Kahn and Papps (2011), using 1980-2000 Census data. When we restrict the sample to married women (Table A3), the impact is reduced to about 27\%, somewhat closer to Blau, Kahn and Papps's result. 
the own labor supply variable can now be interpreted as labor supply relative to the average in one's source country.

Second, columns 5 and 6 of Table 2 show statistically significant negative interaction effects between pre-migration labor supply and female relative activity rate ranging from -0.222 to -0.193 (with visa category excluded and included, respectively). Table 3 employs the coefficients from Table 2 to compute the impact of pre-migration labor supply for women migrating from high vs. low female activity rate countries, as well as the impact of female source country activity rate for women who worked before migration vs. those who did not. Table 3 shows that the impact of working before migration (at the conditional average of roughly 2000 hours per year) on U.S. labor supply is 253-262 hours for those coming from low female labor supply countries and 160-163 hours for women from high female labor supply countries. Moreover, the impact of coming from a high female labor supply country vs. a low female labor supply country is 213-259 hours for those who did not work before migrating and 123-156 hours for those who did work. The effects shown in Table 3 are all highly statistically significant as are the negative interaction terms shown in Table 2, columns 5 and 6.

These comparisons illustrate the degree to which previous labor supply and a workoriented source country culture can substitute for each other in affecting immigrant women's labor supply in the United States. The average effect of prior work experience is about the same size as the average effect of coming from a high vs. a low female labor supply source country. And the negative interaction effects we have just discussed imply that in general source country labor supply is more important for those without prior work experience, while prior work experience is more important for those coming from traditional source countries. This suggests that human capital acquired on the job and human capital transmitted through source country culture act as substitutes. 
While our results suggest substitutability between on-the-job human capital and source country culture, it is also possible that the women from low female labor supply countries who worked prior to migration are relatively more positively selected for labor supply than those who worked prior to migration from high female labor supply countries. Blau and Kahn's (2003) and Olivetti and Petrongolo's (2008) results showing a positive cross-country relationship between the gender pay gap and female labor supply are consistent with view-i.e., that women who are employed in low female participation countries are more positively selected for wages (in terms of their unmeasured characteristics) than their counterparts in high female participation countries for wages. Such a selection pattern would in turn be expected to increase their labor supply. However as Blau and Kahn (2003) argue, it is also possible that high female labor supply lowers women's relative wages through simple supply effects, as long as men and women are imperfect substitutes in production. Nonetheless, if the selection argument is valid, then it may be that the women from traditional source countries who had previous work experience are an especially positively selected group. While the selection mechanism can help explain the small effect of source country female relative activity rate among those who did work before migration, it cannot explain the very large effects of source country female labor supply on women who did not work before migrating. This is the case since under the selection scenario laid out above, women from low female labor supply countries who did not work pre-migration are less negatively selected relative to women from high female labor supply countries who did not work before migrating.

Table 2 also contains some interesting results for other factors that influence immigrant women's labor supply in the United States. Looking first at the impact of individual characteristics, we see that, as would be expected, married women work less than single women, other things equal, impacts that are very similar across specifications. We also find that premigration schooling significantly raises post-migration labor supply in all specifications. The 
impact of a college degree vs. a high school degree is 46-69 hours. It is noteworthy that this effect does not change when we control for source country enrollment rates, a specification that, as we noted in our earlier discussion of the impact of own labor supply, in effect transforms the own schooling variable into one that measures schooling relative to one's source country peers. Years since migration has a positive main coefficient and a negative quadratic coefficient in the analysis of work hours, with a positive derivative for women who have been in the United States for up to 19-20 years (depending on the specification in Table 2), or about $96 \%$ of the population-weighted sample. As noted earlier, while this effect could be interpreted as assimilation, it may also be a cohort effect, since we have only one cross-section. And compared to the omitted "other" visa category, refugees, women with employment visas, and previously undocumented women have especially high labor supply.

The source country characteristics besides female labor supply have some interesting effects on labor supply as well. First, longer distance to the United States is associated with decreased work hours, implying that the disruption effect outweighs the selection effect discussed above. Second, coming from a country in which English is an official language is associated with longer work hours. Both of these effects were also found for recent immigrants by Blau, Kahn, and Papps (2011).

While the results in Table 2 suggest the presence of substitution effects between own labor supply and a female work-oriented culture, it is possible that the source country effects reflect overall preparedness for work in the United States rather than the source country division of labor by gender. Table A2 implicitly tests this view by showing results for the same models estimated for men. While prior work experience has a roughly similar effect for men to its effect for women (a coefficient of about .11), the effects of source country female/male activity ratio and its interaction with pre-migration labor supply are small and insignificant. Thus, our interpretation of these effects for women as reflecting gender and culture would appear valid. 
Tables 4-6 continue our investigation into culture and immigrant behavior by studying the determinants of log hourly earnings among women who were wage and salary workers and not enrolled in school. We measure prior work experience in these Tables by a dummy variable equaling one for those who were employed before migrating. Using annual hours worked before migrating gave similar but less statistically significant results. The results in Table 4 are qualitatively similar to those in Table 2 for annual work hours but less statistically significant. For example, in columns 1, 2 and 4 of Table 4, which show effects of pre-migration labor supply on current wages without any interactions with source country female labor supply, the effect of the respondent's own pre-migration labor supply on wages is 4-5\% and only slightly larger than its standard error. Moreover, in columns 3 and 4, the impact of source country female labor supply is positive, but only about the same size as its standard error. However, the results become stronger when we include an interaction term for these two variables, as shown in columns 5 and 6. For example, in both columns 5 and 6 , the main effect of previous employment is significantly positive, the main effect of the female/male activity ratio is positive and 1.5-2.0 times its standard error, and the interaction effect is negative and 1.4-1.6 times its standard error in absolute value.

Table 5 shows wage results for the fully specified model (i.e., including an interaction term for work before migration and female/male activity rate ratio) using the two alternative selectivity bias correction methods discussed above: (i) assigning nonworkers wages based on equations for those with low (less than 26) weeks worked (columns 1 and 2), and (ii) a two step Heckman (1979) estimator (columns 3 and 4). The selectivity bias-corrected results are qualitatively similar to the OLS results in Table 4. However, the effects in columns 1 and 2 of 
Table 5, which are based on the assignment of wages to nonworkers based on workers with low weeks worked, are particularly large and statistically significant. ${ }^{15}$

Table 6 evaluates the impact of pre-migration labor supply and source country female activity rate on immigrant women's wages based on models including interaction effects. Panel A shows the effect of pre-migration work experience. For women migrating from low female labor supply countries, working before migration raises wages by a statistically significant 8$12 \%$ when we do not control for visa type. Controlling for visa type, the effects are somewhat smaller than this range and less significant. Overall, the results suggest that pre-migration work experience has a modest labor market return in the United States for women from low female labor supply countries. In contrast, working before moving to the United States has virtually no effect on the wages of women moving from high female labor supply countries.

Table 6, Panel B shows the wage effects of migrating from a high female activity rate country vs. one with a low female activity rate. For women without pre-migration work experience, coming from a high female labor supply country raises wages by $10-13 \%$ using the OLS or Heckman methods and 20-35\% using the low work weeks assignment method. These effects are all significant controlling for visa type, but significant only for the low work weeks assignment method when we do not control for visa type. The effects are noticeably smaller for those who worked before migrating: statistically insignificant effects of 3.6-6.6\% using OLS or Heckman methods and a significant $12-24 \%$ using the low work weeks method. ${ }^{16}$

\footnotetext{
15 There are slightly more observations for the analysis which uses workers with low weeks than for the Heckman models since the latter includes number of children, which has some missing cases, as an explanatory variable. In addition, there were slightly different numbers of cases of predicted wages outside the 1 to 250 per hour range than for actual observed wages. Results were virtually identical to those shown in Table 5 when we estimated the selection models on common samples.

${ }^{16}$ We note that both methods of correcting for selection bias may have flaws. Specifically, nonemployed women may differ in unmeasured ways from employed women with low work hours, and the number of children may not be a valid instrument. Table 5 shows that the selectivity variable coefficient ("Inverse Mills Ratio") is not statistically significant in either column 3 or 4; while this does not prove that selectivity bias is not a problem, a formal statistical test accepts the null hypothesis of no selectivity bias. Indeed, the results for our key variables were, as discussed, similar for the Heckman models and the OLS models.
} 
The OLS and selectivity bias-corrected results in Tables 4-6 suggest the following interpretation, which is similar to what we concluded about the determinants of labor supply. Pre-migration labor supply and growing up in a work-oriented culture can both impart skills that are marketable in the US, and these two sources of human capital act as substitutes in the sense that an increase in one reduces the marginal productivity of the other. While we obtain no evidence that pre-migration work experience raises wages in the United States for those who were born in a country with high levels of female labor force participation, pre-migration work experience has potentially substantial positive effects on US wages for those growing up in a country with low female labor participation.

Part of the wage effects obtained in Table 6 for pre-migration labor supply and source country female activity rate may be due to the positive impact of these on US labor supply. However, assuming that the wage results are entirely due to source country culture and human capital acquisition, the combination of the labor supply results in Table 3 and the wage results in Table 6 suggests the possibility that our labor supply results could simply represent a movement along the labor supply curve, since the key variables have the same signs in both equations. Consider first the effect of pre-migration labor supply on wages and work hours. For women moving from low female labor supply countries, the effect of pre-migration work experience on work hours not controlling for visa type is 35.7\% (Table 3, Panel A Column 1), while its effect on log wages using the same specification is at most 0.118 . Thus the hours effect is 3.0 times the wage effect in this specification, and the ratio is even higher for the other specifications in Tables 3 and 6, Panel A. For movements along the labor supply curve to explain the entire work hours effect, the female labor supply elasticity would need to be at least 3, and previous research finds that this parameter was about 0.26-0.32 in the aggregate for women in the United States in 2000 (Blau and Kahn 2007). In other words, for movements along the labor supply curve to fully explain our results for work hours, the labor supply elasticity of immigrant women would need to 
be at least roughly 10 times that of the full population of immigrants and natives. This strongly suggests that pre-migration work experience likely shifts the labor supply to the right as well as contributing to an upward movement along the supply curve.

Looking at the magnitudes of the effects of source country labor supply, the results are slightly less clear but still suggest that higher source country female labor supply acts to shift the US immigrant women's labor supply function to the right. On the one hand, the OLS and Heckman models would require labor supply elasticities in excess of roughly 2.2, again a very high level relative to the estimates of aggregate female labor supply elasticity, in order for movements along the labor supply curve to be the entire mechanism raising US labor supply. On the other hand, using the method of assigning wages based on low weeks workers would only require labor supply elasticities in the 0.9-1.4 range, which, although lower are still substantially higher than the estimates of aggregate female elasticity.

Other results for wage determination can be briefly summarized. First, both Tables 4 and 5 show that pre-migration and US schooling both contribute positively to earnings, with, as would be expected, a substantially larger effect of US schooling. Second, in results not shown but available upon request, Black, Hispanic and Asian immigrants earn less than white immigrants, all else equal. Third, growing up in an English-speaking or English-official country raises earnings. And, finally, employment visas are associated with especially high earnings.

\section{Supplementary Analyses}

As mentioned above, we performed a number of alternative analyses which, in each case, found similar results to those reported above. First, Tables A3 and A4 report labor supply and wage results for married women. The findings for the key variables are quite similar in magnitude and significance level to those for the whole sample. Second, we added the country's 
female 1980-90 emigration rate to the basic labor supply models, and the results (available upon request) were unchanged. The emigration rate had a positive, but insignificant effect on United States labor supply. The positive impact is consistent with the positive selection among stayers, although this effect did not influence our basic conclusions about cultural and human capital. Therefore, possible plans for return migration are not part of the explanation for the basic labor supply results in Tables 2 and 3. Third, we controlled for region and religious tradition in studying labor supply. The basic labor supply results, also available from the authors on request, for pre-migration employment and source country female labor supply were again unchanged. Not surprisingly, the religious tradition variables had negative effects relative to the omitted category-No Religion. Thus, the basic labor supply results shown in Tables 2 and 3 also hold up within region and religious groups. ${ }^{17}$ Fourth, we used two different dependent variables in analyzing the determinants of labor supply: labor force participation and the probability of current employment. The results were in both cases very similar to those in Table 2. Finally, in our basic analyses of labor supply, we additionally controlled for schooling in the US and fertility. The results were again very similar.

\section{Conclusions}

In this paper we use New Immigrant Survey data to investigate the impact of immigrant women's own labor supply prior to migrating and source country characteristics to provide evidence on the role of human capital and cultural capital in affecting their wages and labor supply in the United States. We find, as expected, that women who migrate from countries with relatively high levels of female labor supply work more in the United States. Moreover, most of

\footnotetext{
${ }^{17}$ Respondents were allowed to list more than one religious tradition, and 13 of the 2769 women (i.e., $0.47 \%$ ) with complete data listed a second religion that was different from the first one they listed (including No Religion as a possible second option). Our basic analysis used the respondent's first response to the religion question in forming the dummy variables, but the results were virtually identical when we excluded the 13 women who listed more than one religion or included these respondents with a dummy variable indicating multiple responses to the religion question.
} 
this effect remains when we further control for each woman's own labor supply prior to migrating, which itself also strongly affects labor supply in the United States. Moreover, we find a significantly negative interaction between pre-migration labor supply and source country female labor supply. This means that the impact of source country female labor supply is much stronger for those who did not themselves work for pay before migrating than among those with work experience in their source country, while the impact of pre-migration work experience is larger for those from source countries with low female labor supply than for those from high female labor supply countries. We obtain broadly similar effects analyzing the determinants of hourly earnings among the employed in the United States, although the effects are not always significant.

These results suggest an important role for culture and norms in affecting immigrant women's labor supply, since the effect of source country female labor supply on immigrant women's work hours in the United States is still strong even controlling for the immigrant's own pre-migration labor supply. The negative interaction effects between previous work experience and source country female labor supply on immigrant women's US work hours and wages suggest that cultural capital can substitute for individual job-related human capital in affecting preparedness for work in the United States. And, the very large positive effect of source country female labor supply on the work hours of women who did not work before migrating that the interaction effect implies further reinforces the inference that broader cultural or social capital effects on women's labor supply in the United States can be substantial. 


\section{References}

Ahmed, Bashir and J. Gregory Robinson, "Estimates of Emigration of the Foreign-Born Population: 1980-1990," U.S. Bureau of the Census Population Division Working Paper No. 9, December 1994.

Akresh, Ilana Redstone, "Occupational Trajectories of Legal US Immigrants: Downgrading and Recovery," Population and Development Review 34, no. 3 (September 2008): 435-456.

Antecol, Heather, "An Examination of Cross-Country Differences in the Gender Gap in Labor Force Participation Rates," Labour Economics 7, no. 4 (July 2000): 409-426.

Barro, Robert J., and Jong-Wha Lee, "Sources of Economic Growth." Carnegie-Rochester Conference Series on Public Policy 40, (1994): 1-46.

Blau, Francine D. "The Fertility of Immigrant Women: Evidence from High-Fertility Source Countries," in George J. Borjas and Richard B. Freeman, eds., Immigration and the Work force: Economic Consequences for the United States and Source Areas. Chicago, IL: University of Chicago Press, 1992, pp. 93-133.

Blau, Francine D. and Lawrence M. Kahn, "Understanding International Differences in the Gender Pay Gap,” Journal of Labor Economics 21, No. 1 (January 2003): 106-144.

Blau, Francine D. and Lawrence M. Kahn, “The U.S. Gender Pay Gap in the 1990s: Slowing Convergence," Industrial and Labor Relations Review 60, No. 1 (October 2006): 45-66.

Blau, Francine D. and Lawrence M. Kahn, "Changes in the Labor Supply Behavior of Married Women: 1980-2000,” Journal of Labor Economics 25, No. 3 (July 2007): 393-438.

Blau, Francine D., Lawrence M. Kahn, Joan Moriarty, and Andre Souza, "The Role of the Family in Immigrants' Labor-Market Activity: An Evaluation of Alternative Explanations: Comment," American Economic Review, 93, No. 1 (March 2003): 429447.

Blau, Francine D., Lawrence M. Kahn and Kerry L. Papps, "Gender, Source Country Characteristics and Labor Market Assimilation Among Immigrants: 1980-2000," Review of Economics and Statistics 93, No. 1 (February 2011): 43-58.

Bleakley, Hoyt and Aimee Chin, "Language Skills and Earnings: Evidence from Childhood Immigrants" Review of Economics and Statistics 86, No. 2 (May 2004): 481-496.

Borjas, George J., "Assimilation, Changes in Cohort Quality, and the Earnings of Immigrants." Journal of Labor Economics 3, No. 4 (October 1985): 463-489.

Chiswick, Barry R. "The Effect of Americanization on the Earnings of Foreign Born Men." Journal of Political Economy 86, No. 5 (October 1978): 897-921. 
Fernández, Raquel, "Culture and Economics," in the New Palgrave Dictionary of Economics, 2nd edition, edited by Steven N. Durlauf and Lawrence E. Blume (Basingstoke and New York: Palgrave Macmillan, 2008), pp. 333-340.

Fernández, Raquel and Alessandra Fogli, "Fertility: The Role of Culture and Family Experience," Journal of the European Economic Association 4, Nos. 2-3 (April-May 2006): 552-561.

Fernández, Raquel and Alessandra Fogli, "Culture: An Empirical Investigation of Beliefs, Work, and Fertility,”American Economic Journal: Macroeconomics 1 (January 2009): 146-177.

Heckman, James J., "Sample Selection Bias as a Specification Error,” Econometrica 47, No. 1 (January 1979): 153-162.

Jaeger, David A., "Reconciling the Old and New Census Bureau Education Questions: Recommendations for Researchers," Journal of Business \& Economic Statistics 15, issue 3 (July 1997): 300-309.

Hoefer, Michael, Nancy Rytina, and Christopher Campbell, "Estimates of the Unauthorized Immigrant Population Residing in the United States: January 2006," U.S. Department of Homeland Security, Office of Immigration Statistics Policy Directorate Report, August 2007.

Juhn, Chinhui, "Decline of Male Labor Market Participation: The Role of Declining Market Opportunities," Quarterly Journal of Economics 107, No. 1 (February 1992): 79-121.

Juhn, Chinhui, and Kevin M. Murphy, "Wage Inequality and Family Labor Supply," Journal of Labor Economics 15, No. 1 (January 1997 Part 1): 72-97.

Lubotsky, Darren, "Chutes or Ladders? A Longitudinal Analysis of Immigrant Earnings," Journal of Political Economy 115, no. 5 (October 2007): 820-867.

Neal, Derek, "The Measured Black-White Wage Gap among Women Is Too Small," Journal of Political Economy, 112, No. 1 (February 2004, pt. 2 Supplement): S1-S28.

Neal, Derek A. and William R. Johnson, "The Role of Premarket Factors in Black-White Wage Differences," Journal of Political Economy 104, No. 5 (October 1996): 869-895.

Olivetti, Claudia and Barbara Petrongolo, "Unequal Pay or Unequal Employment? A CrossCountry Analysis of Gender Gaps," Journal of Labor Economics 26, No. 4 (October 2008): 621-654.

United Nations Statistics Division (UNSD), "Fertility Rate (13700): Total Fertility Rate" (UN Pop. Div. Quinquennial Estimates and Projections) http://unstats.un.org/unsd/cdb/cdb_series_xrxx.asp?series_code=13700. 
United Nations Statistics Division (UNSD), “GDP (22918): Gross Domestic Product at Market Prices, Constant US\$” (World Bank Estimates) http://unstats.un.org/unsd/cdb/cdb_series_xrxx.asp?series_code=29918.

United Nations Statistics Division (UNSD), "Population (13660): Population Total” (UN Pop. Div. Annual Estimates and Projections) [code 13660] http://unstats.un.org/unsd/cdb/cdb_series_xrxx.asp?series_code $=13660$.

United Nations Statistics Division (UNSD), "Economic Activity Rate (4270): Economic Activity Rate by Sex, Thirteen Age Groups, 1950-2010" (ILO Estimates and Projections) http://unstats.un.org/unsd/cdb/cdb_series_xrxx.asp?series_code=4270.

United Nations Statistics Division (UNSD), "Economically Activity Population (4230): Economically Active Population by Sex, Thirteen Age Groups, 1950-2010” (ILO Estimates and Projections) http://unstats.un.org/unsd/cdb/cdb_series_xrxx.asp?series_code=4230.

U.S. Arms and Control Disarmament Agency, World Military Expenditures and Arms Transfers (various issues).

U.S. Department of Justice, Annual Report of the Immigration and Naturalization Service. Washington, D.C.: U.S. Government Printing Office, various issues.

U.S. Department of State, World Military Expenditures and Arms Transfers (various issues).

U.S. Immigration and Naturalization Service, Statistical Yearbook of the Immigration and Naturalization Service Washington, D.C.: U.S. Government Printing Office, various issues.

World Almanac and Book of Facts. New York: World Almanac Books, 1999. 


\section{Appendix: Construction of the Source Country Variables}

The source country characteristics described below were collected at five-year intervals for the period 1950 to 2000 and were originally used in Blau, Kahn and Papps (2011). To form a consistent list of source countries, we combine some countries which were not available in some Census years (e.g. subsets of countries in Africa, the Pacific Islands, and the West Indies) and countries that split or combined between 1980 and 2000 (e.g. the former USSR countries, East and West Germany, former Czechoslovakia, and former Yugoslavia). Some countries were combined because data on source country characteristics were only available in a combined form. The data set includes 106 source countries in total. The characteristics for each composite group are the average values over constituent countries weighted by each country's population age 18 to 65 from the 2000 Census $1 \%$ extract. Due to missing values of source country variables in some years, we have, in cases, interpolated for intervening years, used earliest (most recent) values for preceding (subsequent) years, and imputed source country characteristics from neighboring countries. Source country characteristics were matched to arrival cohorts as follows: 1950-1959: 1955; 1960-1964: 1960; 1965-1969: 1965; 1970-1974: 1970; 1975-1979: 1975; 1980-1984: 1980; 1985-1990: 1985; 1991-1994: 1990; 1995-2000: 1995.

We then merged the data set into the NIS's list of source countries. In some cases, we had to aggregate countries from the source country data set, since the NIS includes only 29 source countries or country groups. In the aggregation, we used separate weighted averages by gender by source country for immigrants who arrived in the last 5 years, taken from the 2000 Census of Population. The averages used Census sampling weights. 
Source Country Characteristics: Definitions and Sources

\begin{tabular}{ll}
\hline Variable & Description \\
\hline Fertility & Total fertility rate: the number of children that would be born per woman, assuming no \\
& female mortality at child bearing ages and the age-specific fertility rates of a specified \\
& country and reference period. The data are available between 1955 and 2000 at five \\
& year intervals. Source: United Nations Statistics Division, Series 13700 (2006). \\
GDP per Capita & GDP per capita (1995 US \$): GDP is an aggregate measure of production equal to the \\
& sum of the gross values added of all resident institutional units engaged in production. \\
& The total population of a country may comprise either all usual residents of the \\
& country (de jure population) or all persons present in the country (de facto population) \\
& at the time of the census. The data are available annually between 1960 and 2000. \\
& Source: United Nations Statistics Division, Series 29918 and 13660 (2006), with \\
& supplemental data from U.S. Arms and Control Disarmament Agency and U.S. \\
& Department of State,World Military Expenditures and Arms Transfers (various issues).
\end{tabular}

Female/Male Activity

Rate

Primary School

Enrollment Rate

Secondary School

Enrollment Rate

English-Speaking

Country

English Official

Language

Emigration Rate

Distance to US
Female LFP / Male LFP: Economically active population ("usually active" or "currently active" (currently active is also known as "the labor force")) comprises all persons who furnish the supply of labor for the production of economic goods and services (employed and unemployed, including those seeking work for the first time), as defined by the System of National Accounts (SNA). The rates are calculated for individuals age 15 and up. The data are available between 1950 and 2000 at ten year intervals and in 1995. Source: United Nations Statistics Division, Series 4270 and 4230 (2006).

Female or male primary school enrollment rate: Gross enrollment ratio is the ratio of total enrollment, regardless of age, to the population of the age group that officially corresponds to that level of education in question. The World Bank data are available in 1970, 1975, 1980, 1985, and 1990-1998; Barro-Lee data are available between 1960 and 1985 at five year intervals. Source: World Bank World Development Indicators CD-Rom, Series SE.PRM.ENRR.FE (2002), with supplemental data from Barro and Lee (1994).

Female or male secondary school enrollment rate: Gross enrollment ratio is the ratio of total enrollment, regardless of age, to the population of the age group that officially corresponds to that level of education in question. The World Bank data are available in 1970, 1975, 1980, 1985, and 1990-1998; Barro-Lee data are available between 1960 and 1985 at five year intervals. Source: World Bank World Development Indicators CD-Rom, Series SE.SEC.ENRR.FE (2002), with supplemental data from Barro and Lee (1994).

English speaking country. Source: Bleakley and Chin (2004); their data were from the World Almanac and Book of Facts (1999).

English is an official language of the country (for non-English-Speaking countries). Source: Bleakley and Chin (2004); their data were from the World Almanac and Book of Facts (1999).

Annual female emigration rate: the annual number of female emigrants between 1980 and 1990 divided by the average of the 1980 and 1990 female immigrant populations. Source: Annual emigration estimates by country from Ahmed and Robinson (1994).

Distance to the U.S. (miles): computed as the distance between the capital of the foreign country and the closest of three U.S. gateways - New York, Los Angeles or Miami. See http://www.indo.com/distance/ and http://www.cia.gov/cia/publications/factbook 
Table 1: Means for the Full Sample and by Birth Region, Adult Immigrants, NIS

\begin{tabular}{|c|c|c|c|c|c|c|c|c|}
\hline & \multicolumn{8}{|c|}{ Latin America and } \\
\hline & \multicolumn{2}{|c|}{ Full Sample } & \multicolumn{2}{|c|}{ South and East Asia } & \multicolumn{2}{|c|}{ Caribbean } & \multicolumn{2}{|c|}{ Europe and Central Asia } \\
\hline & Women & Men & Women & Men & Women & Men & Women & Men \\
\hline \multicolumn{9}{|l|}{ A. Personal Characteristics } \\
\hline Annual Work Hours in US & 735.486 & 1399.277 & 618.773 & 1214.536 & 815.425 & 1520.228 & 888.304 & 1470.217 \\
\hline Currently In Labor Force in US & 0.594 & 0.907 & 0.588 & 0.879 & 0.585 & 0.932 & 0.667 & 0.906 \\
\hline Currently in School in US & 0.088 & 0.081 & 0.072 & 0.060 & 0.080 & 0.067 & 0.128 & 0.071 \\
\hline Currently Employed & 0.407 & 0.724 & 0.350 & 0.636 & 0.434 & 0.794 & 0.513 & 0.747 \\
\hline Annual Work Hours Before Migrating & 1041.368 & 1512.841 & 1128.387 & 1532.505 & 860.416 & 1345.353 & 1368.044 & 1812.899 \\
\hline Worked Before Migrating & 0.532 & 0.686 & 0.531 & 0.674 & 0.471 & 0.625 & 0.721 & 0.809 \\
\hline Log hourly earnings in US & 2.290 & 2.494 & 2.334 & 2.632 & 2.155 & 2.353 & 2.425 & 2.724 \\
\hline Married, Spouse Present & 0.785 & 0.780 & 0.859 & 0.829 & 0.717 & 0.756 & 0.820 & 0.830 \\
\hline Number of Own Children & 1.757 & 1.531 & 1.417 & 1.549 & 2.330 & 1.860 & 1.133 & 1.141 \\
\hline Age & 37.932 & 38.166 & 38.195 & 40.466 & 38.995 & 37.752 & 36.331 & 38.144 \\
\hline Years of Schooling Before Migrating & 11.902 & 12.601 & 12.644 & 13.802 & 10.144 & 10.464 & 14.130 & 14.084 \\
\hline Years of Schooling in US & 0.381 & 0.579 & 0.430 & 0.603 & 0.276 & 0.472 & 0.535 & 0.605 \\
\hline Years Since Migration & 4.686 & 5.964 & 2.860 & 4.055 & 6.794 & 8.395 & 3.792 & 4.950 \\
\hline Other Visa & 0.086 & 0.095 & 0.076 & 0.133 & 0.134 & 0.118 & 0.020 & 0.037 \\
\hline Family Visa & 0.625 & 0.476 & 0.666 & 0.448 & 0.655 & 0.572 & 0.475 & 0.368 \\
\hline Employment Visa & 0.101 & 0.145 & 0.203 & 0.331 & 0.026 & 0.040 & 0.081 & 0.124 \\
\hline Diversity Visa & 0.073 & 0.120 & 0.030 & 0.046 & 0.007 & 0.015 & 0.256 & 0.285 \\
\hline Refugee Visa & 0.061 & 0.084 & 0.025 & 0.034 & 0.040 & 0.063 & 0.165 & 0.180 \\
\hline Legalization Visa & 0.055 & 0.080 & 0.000 & 0.008 & 0.138 & 0.193 & 0.002 & 0.005 \\
\hline Born in South/East Asia & 0.347 & 0.282 & 1.000 & 1.000 & 0.000 & 0.000 & 0.000 & 0.000 \\
\hline Born in Latin America/Caribbean & 0.393 & 0.389 & 0.000 & 0.000 & 1.000 & 1.000 & 0.000 & 0.000 \\
\hline Born in Sub-Saharan Africa & 0.062 & 0.087 & 0.000 & 0.000 & 0.000 & 0.000 & 0.000 & 0.000 \\
\hline Born in Europe/Central Asia & 0.137 & 0.171 & 0.000 & 0.000 & 0.000 & 0.000 & 1.000 & 1.000 \\
\hline Hispanic & 0.344 & 0.328 & 0.012 & 0.016 & 0.857 & 0.824 & 0.008 & 0.007 \\
\hline Asian, Nonhispanic & 0.340 & 0.277 & 0.946 & 0.940 & 0.008 & 0.009 & 0.017 & 0.013 \\
\hline Black, Nonhispanic & 0.104 & 0.140 & 0.005 & 0.002 & 0.110 & 0.144 & 0.003 & 0.007 \\
\hline Other, Nonhispanic & 0.011 & 0.011 & 0.019 & 0.031 & 0.008 & 0.004 & 0.000 & 0.002 \\
\hline White, Nonhispanic & 0.202 & 0.244 & 0.017 & 0.011 & 0.018 & 0.019 & 0.973 & 0.971 \\
\hline
\end{tabular}


Table 1 (cont'd): Means for the Full Sample and by Birth Region, Adult Immigrants, NIS

\begin{tabular}{|c|c|c|c|c|c|c|c|c|}
\hline & \multirow{2}{*}{\multicolumn{2}{|c|}{ Full Sample }} & \multirow{2}{*}{\multicolumn{2}{|c|}{ South and East Asia }} & \multicolumn{2}{|c|}{ Latin America and } & \multirow{2}{*}{\multicolumn{2}{|c|}{ Europe and Central Asia }} \\
\hline & & & & & Carik & ean & & \\
\hline & Women & Men & Women & Men & Women & Men & Women & Men \\
\hline \multicolumn{9}{|l|}{ B. Source Country Characteristics } \\
\hline Female/Male Activity Ratio in Source Country & 0.598 & 0.591 & 0.667 & 0.651 & 0.490 & 0.486 & 0.728 & 0.723 \\
\hline Fertility in Source Country & 3.125 & 3.295 & 2.921 & 3.030 & 3.407 & 3.582 & 1.647 & 1.721 \\
\hline Real GDP in Source Country (1995 US dollars) & 4169.415 & 4079.772 & 3650.272 & 3315.347 & 2271.098 & 2095.232 & 9917.695 & 9821.048 \\
\hline Secondary Enrollment Rate in Source Country & 63.480 & 63.487 & 62.428 & 67.669 & 57.587 & 51.813 & 94.119 & 93.483 \\
\hline Primary Enrollment Rate in Source Country & 101.611 & 104.986 & 101.841 & 110.101 & 108.523 & 108.223 & 99.215 & 100.158 \\
\hline Distance from Source Country to US (miles) & 4199.027 & 4082.135 & 7035.855 & 7036.534 & 1309.577 & 1268.126 & 4326.533 & 4281.970 \\
\hline English-Speaking Source Country & 0.059 & 0.076 & 0.000 & 0.000 & 0.059 & 0.077 & 0.065 & 0.115 \\
\hline \multicolumn{9}{|l|}{ English-Official but not English-Speaking } \\
\hline Source Country & 0.204 & 0.192 & 0.491 & 0.514 & 0.000 & 0.000 & 0.000 & 0.000 \\
\hline Proportion Refugees & 0.072 & 0.077 & 0.046 & 0.040 & 0.039 & 0.047 & 0.214 & 0.194 \\
\hline Sample size & 2861 & 2622 & 1011 & 900 & 980 & 728 & 488 & 499 \\
\hline
\end{tabular}


Table 2: Selected OLS Results for the Determinants of Annual Work Hours (including zeroes), Adult Immigrant Women

\begin{tabular}{|c|c|c|c|c|c|c|}
\hline & (1) & (2) & (3) & (4) & (5) & (6) \\
\hline \multirow[t]{2}{*}{ Annual Work Hours Before Migrating } & $0.101 * *$ & $0.104 * *$ & & $0.100 * *$ & $0.236 * *$ & $0.217^{* *}$ \\
\hline & $(0.015)$ & $(0.015)$ & & $(0.015)$ & $(0.052)$ & $(0.053)$ \\
\hline \multirow[t]{2}{*}{ Female/Male Activity Ratio in Source Country } & & & $982.301^{* *}$ & $883.039 * *$ & $1117.018^{* *}$ & $917.687^{* *}$ \\
\hline & & & $(260.354)$ & $(253.166)$ & $(243.831)$ & $(219.276)$ \\
\hline Interaction: Annual Work Hours Before & & & & & $-0.222 * *$ & $-0.193^{*}$ \\
\hline Migrating x Female/Male Activity Ratio & & & & & $(0.071)$ & $(0.073)$ \\
\hline \multirow[t]{2}{*}{ Married, Spouse Present } & $-186.398 * *$ & $-188.218 * *$ & k $-162.119 *$ & $-172.546 * *$ & $-171.304 * *$ & $-167.548 * *$ \\
\hline & $(51.906)$ & (59.113) & $(59.555)$ & $(57.509)$ & $(57.453)$ & $(57.915)$ \\
\hline \multirow[t]{2}{*}{ Years of Schooling Before Migrating } & $15.670 * *$ & $11.876^{*}$ & $17.365^{* *}$ & $12.179 *$ & $11.536^{*}$ & $11.662^{*}$ \\
\hline & (4.697) & $(4.864)$ & $(4.738)$ & $(4.722)$ & $(4.716)$ & (4.938) \\
\hline \multirow[t]{2}{*}{ Years Since Migration (YSM) } & $137.957^{* *}$ & $140.377^{* *}$ & $141.136^{* *}$ & $142.323^{* *}$ & $141.601 * *$ & $121.725^{* *}$ \\
\hline & $(10.316)$ & (11.112) & $(10.070)$ & $(10.725)$ & (10.593) & (9.438) \\
\hline \multirow[t]{2}{*}{ YSM squared (/100) } & $-366.620 * *$ & $-364.177 * *$ & k $-364.149 * *$ & k $-371.043^{* *}$ & $-368.464 * *$ & $-304.644 * *$ \\
\hline & (42.991) & (43.010) & $(45.401)$ & (45.097) & $(44.781)$ & (39.725) \\
\hline \multirow[t]{2}{*}{ Fertility in Source Country } & & -35.442 & 42.385 & 32.749 & 30.549 & 32.540 \\
\hline & & (47.452) & (42.654) & (36.069) & (34.675) & (35.786) \\
\hline \multirow[t]{2}{*}{ Real GDP in Source Country (\$US/1000) } & & -1.915 & 2.873 & 3.346 & 2.447 & 3.673 \\
\hline & & (8.085) & (7.066) & (6.584) & (6.641) & (5.708) \\
\hline \multirow[t]{2}{*}{ Secondary Enrollment Rate in Source Country } & & 2.098 & 2.952 & 2.182 & 2.047 & 2.144 \\
\hline & & $(2.330)$ & (1.867) & (1.617) & (1.599) & (1.473) \\
\hline \multirow[t]{2}{*}{ Primary Enrollment Rate in Source Country } & & -2.236 & -2.028 & -2.144 & -2.222 & 1.165 \\
\hline & & $(2.122)$ & $(2.077)$ & $(2.065)$ & $(2.039)$ & $(1.686)$ \\
\hline \multirow{2}{*}{$\begin{array}{l}\text { Distance from Source Country to US } \\
\text { (miles/1000) }\end{array}$} & & $-39.274^{*}$ & $-61.194 * *$ & $-63.299 * *$ & $-62.929 * *$ & $-41.812^{*}$ \\
\hline & & $(18.346)$ & $(19.905)$ & $(18.597)$ & $(18.245)$ & $(17.494)$ \\
\hline \multirow[t]{2}{*}{ English-Speaking Source Country } & & 31.080 & -139.015 & -116.874 & -106.963 & -17.000 \\
\hline & & $(154.822)$ & $(142.473)$ & $(136.711)$ & $(134.463)$ & $(114.442)$ \\
\hline \multirow{2}{*}{$\begin{array}{l}\text { English-Official but not English-Speaking } \\
\text { Source Country }\end{array}$} & & $276.826^{* *}$ & $380.203^{* *}$ & $404.700 * *$ & $395.647^{* *}$ & $321.082 * *$ \\
\hline & & $(92.393)$ & $(80.557)$ & $(82.262)$ & $(82.092)$ & $(66.290)$ \\
\hline \multirow[t]{2}{*}{ Family Visa } & & & & & & $193.079 *$ \\
\hline & & & & & & $(72.409)$ \\
\hline \multirow[t]{2}{*}{ Employment Visa } & & & & & & $410.335^{* *}$ \\
\hline & & & & & & $(134.603)$ \\
\hline \multirow[t]{2}{*}{ Diversity Visa } & & & & & & 153.012 \\
\hline & & & & & & (97.697) \\
\hline \multirow[t]{2}{*}{ Refugee Visa } & & & & & & $600.809 * *$ \\
\hline & & & & & & (89.049) \\
\hline \multicolumn{2}{|l|}{ Legalization Visa } & & & & & $538.123 * *$ \\
\hline $\mathrm{N}$ & 2861 & 2861 & 2861 & 2861 & 2861 & 2861 \\
\hline Adjusted R squared & 0.220 & 0.226 & 0.219 & 0.231 & 0.233 & 0.249 \\
\hline
\end{tabular}

$+p<0.10, * p<0.05, * * p<0.01$

Note: Sample includes those who migrated at age 18 or later and who are currently no more than 65 years old. Standard errors are clustered at the source country level. Other controls include race/ethnicity, age and age squared. 
Table 3: Effects of Pre-Migration Employment and Source Country Female Labor Supply on Immigrant Women's Annual Work Hours

A. Hours Effects of Pre-Migration Employment vs. No Pre-Migration Employment

\begin{tabular}{|c|c|c|c|c|}
\hline \multirow[b]{2}{*}{ Premigration Employment } & \multicolumn{2}{|c|}{$\begin{array}{c}\text { Low Female Relative Activity Rate } \\
\text { (25th percentile) }\end{array}$} & \multicolumn{2}{|c|}{$\begin{array}{c}\text { HIgh Female Relative Activity Rate } \\
\text { (75th percentile) }\end{array}$} \\
\hline & $262.6^{* *}$ & $252.9 * *$ & $159.6 * *$ & $162.6 * *$ \\
\hline$\%$ of Mean Hours & $35.7 \%$ & $34.2 \%$ & $21.7 \%$ & $22.1 \%$ \\
\hline Visa category variables included? & no & yes & no & yes \\
\hline
\end{tabular}

\section{B. Hours Effect of High vs. Low Female Female Activity Rate Country}

\begin{tabular}{lcccc}
\hline & No Pre-Migration Work Experience & \multicolumn{2}{c}{ Worked Before Migration } \\
\hline 75th vs. 25th Percentile Female Activity Rate Country & $259.0^{* *}$ & $212.8^{* *}$ & $156.0^{*}$ & $123.5^{*}$ \\
$\%$ of Mean Hours & $35.2 \%$ & $28.9 \%$ & $21.2 \%$ & $16.8 \%$ \\
Visa category variables included? & no & yes & no & yes \\
\hline
\end{tabular}

$* \mathrm{p}<.05 * * \mathrm{p}<.01$

Note: Estimates are based on Table 2 models interacting pre-migration employment and female relative activity ratio. Premigration hours are set to the mean among those who worked (roughly 2000 hours). The 25th percentile country is Dominican Republic (relative activity rate=0.47); and the 75th percentile country is Sub-Saharan Africa (relative activity rate=.70). 
Table 4: Selected OLS Results for the Determinants of Log Hourly Earnings, Adult Immigrant Women

\begin{tabular}{|c|c|c|c|c|c|c|}
\hline & (1) & $(2)$ & (3) & (4) & (5) & (6) \\
\hline \multirow[t]{2}{*}{ Worked Before Migrating } & 0.043 & 0.053 & & 0.053 & $0.238^{*}$ & $0.191+$ \\
\hline & $(0.042)$ & $(0.045)$ & & $(0.045)$ & $(0.115)$ & $(0.102)$ \\
\hline \multirow[t]{2}{*}{ Female/Male Activity Ratio in Source Country } & & & 0.320 & 0.321 & 0.500 & $0.554+$ \\
\hline & & & $(0.328)$ & $(0.318)$ & $(0.330)$ & $(0.277)$ \\
\hline Interaction: Worked Before Migrating $\mathrm{x}$ & & & & & -0.315 & -0.270 \\
\hline Female/Male Activity Ratio & & & & & $(0.195)$ & $(0.195)$ \\
\hline \multirow[t]{2}{*}{ Married, Spouse Present } & -0.050 & -0.060 & -0.048 & -0.053 & -0.055 & -0.039 \\
\hline & $(0.051)$ & $(0.044)$ & $(0.042)$ & $(0.042)$ & $(0.041)$ & $(0.026)$ \\
\hline \multirow[t]{2}{*}{ Years of Schooling Before Migrating } & $0.045^{* *}$ & $0.040 * *$ & $0.041^{* *}$ & $0.040 * *$ & $0.039 * *$ & $0.032 * *$ \\
\hline & $(0.007)$ & $(0.006)$ & $(0.007)$ & $(0.007)$ & $(0.006)$ & $(0.005)$ \\
\hline \multirow[t]{2}{*}{ Years of Schooling in US } & $0.130 * *$ & $0.132^{* *}$ & $0.131 * *$ & $0.133^{* *}$ & $0.132^{* *}$ & $0.132 * *$ \\
\hline & $(0.021)$ & $(0.017)$ & $(0.017)$ & $(0.017)$ & $(0.017)$ & $(0.018)$ \\
\hline \multirow[t]{2}{*}{ Years Since Migration (YSM) } & $0.045^{* *}$ & $0.050 * *$ & $0.050 * *$ & $0.050 * *$ & $0.050 * *$ & $0.032 * *$ \\
\hline & $(0.010)$ & $(0.011)$ & $(0.011)$ & $(0.011)$ & $(0.010)$ & $(0.007)$ \\
\hline \multirow[t]{2}{*}{ YSM squared (/100) } & $-0.121^{* *}$ & $-0.132 * *$ & $-0.133^{* *}$ & $-0.132 * *$ & $-0.128 * *$ & $-0.074^{*}$ \\
\hline & $(0.037)$ & $(0.033)$ & $(0.033)$ & $(0.034)$ & $(0.033)$ & $(0.032)$ \\
\hline \multirow[t]{2}{*}{ Fertility in Source Country } & & -0.026 & 0.001 & -0.003 & -0.005 & 0.007 \\
\hline & & $(0.048)$ & $(0.053)$ & $(0.051)$ & $(0.050)$ & $(0.049)$ \\
\hline \multirow[t]{2}{*}{ Real GDP in Source Country (1995 \$US/1000) } & & 0.000 & 0.002 & 0.002 & 0.002 & 0.004 \\
\hline & & $(0.008)$ & $(0.008)$ & $(0.008)$ & $(0.008)$ & $(0.006)$ \\
\hline \multirow[t]{2}{*}{ Secondary Enrollment Rate in Source Country } & & -0.001 & -0.001 & -0.002 & -0.001 & -0.001 \\
\hline & & (0.003) & $(0.002)$ & $(0.002)$ & $(0.002)$ & $(0.002)$ \\
\hline \multirow[t]{2}{*}{ Primary Enrollment Rate in Source Country } & & 0.002 & 0.003 & 0.003 & 0.003 & 0.002 \\
\hline & & $(0.002)$ & $(0.003)$ & $(0.002)$ & $(0.002)$ & $(0.002)$ \\
\hline \multicolumn{7}{|l|}{ Distance from Source Country to US } \\
\hline \multirow[t]{2}{*}{ (miles/1000) } & & -0.018 & $-0.025+$ & $-0.026+$ & $-0.026+$ & -0.022 \\
\hline & & $(0.013)$ & $(0.015)$ & $(0.014)$ & $(0.014)$ & $(0.014)$ \\
\hline \multirow[t]{2}{*}{ English-Speaking Source Country } & & $0.345^{*}$ & $0.291+$ & $0.289+$ & $0.288+$ & 0.129 \\
\hline & & $(0.150)$ & $(0.155)$ & $(0.152)$ & $(0.153)$ & $(0.177)$ \\
\hline \multirow{2}{*}{$\begin{array}{l}\text { English-Official but not English-Speaking } \\
\text { Source Country }\end{array}$} & & $0.343^{* *}$ & $0.373^{* *}$ & $0.383^{* *}$ & $0.387^{* *}$ & $0.277^{* *}$ \\
\hline & & $(0.113)$ & $(0.107)$ & $(0.102)$ & $(0.103)$ & $(0.091)$ \\
\hline \multirow[t]{2}{*}{ Family Visa } & & & & & & $0.154^{* *}$ \\
\hline & & & & & & (0.039) \\
\hline \multirow[t]{2}{*}{ Employment Visa } & & & & & & $0.639 * *$ \\
\hline & & & & & & $(0.095)$ \\
\hline \multirow[t]{2}{*}{ Diversity Visa } & & & & & & -0.088 \\
\hline & & & & & & $(0.113)$ \\
\hline \multirow[t]{2}{*}{ Refugee Visa } & & & & & & $0.111^{*}$ \\
\hline & & & & & & $(0.053)$ \\
\hline \multirow[t]{2}{*}{ Legalization Visa } & & & & & & $0.211^{* *}$ \\
\hline & & & & & & $(0.071)$ \\
\hline $\mathrm{N}$ & 1005 & 1005 & 1005 & 1005 & 1005 & 1005 \\
\hline Adjusted R squared & 0.277 & 0.310 & 0.310 & 0.311 & 0.311 & 0.395 \\
\hline
\end{tabular}

$+p<0.10, * p<0.05, * * p<0.01$ 
Table 5 : Selected Results for Log Wage Regressions, All Women, Alternative Selectivity Bias Corrections (NIS)

\begin{tabular}{|c|c|c|c|c|}
\hline & \multicolumn{2}{|c|}{$\begin{array}{l}\text { Nonworkers Assigned } \\
\text { Predicted Wages Based on } \\
\text { Low Weeks Workers }\end{array}$} & \multicolumn{2}{|c|}{$\begin{array}{l}\text { Heckman Selectivity Bias } \\
\text { Correction, Number of } \\
\text { Children in First Stage }\end{array}$} \\
\hline & (1) & (2) & (3) & (4) \\
\hline Worked Before Migrating & $\begin{array}{l}0.351^{* *} \\
(0.050)\end{array}$ & $\begin{array}{l}0.258^{* *} \\
(0.039)\end{array}$ & $\begin{array}{l}0.218^{*} \\
(0.111)\end{array}$ & $\begin{array}{c}0.149 \\
(0.128)\end{array}$ \\
\hline Female/Male Activity Ratio in Source Country & $\begin{array}{l}1.522^{* *} \\
(0.116)\end{array}$ & $\begin{array}{l}0.878^{* *} \\
(0.089)\end{array}$ & $\begin{array}{c}0.454 \\
(0.309)\end{array}$ & $\begin{array}{l}0.474^{*} \\
(0.203)\end{array}$ \\
\hline $\begin{array}{l}\text { Interaction: Worked Before Migrating x } \\
\text { Female/Male Activity Ratio }\end{array}$ & $\begin{array}{l}-0.494^{* *} \\
(0.082)\end{array}$ & $\begin{array}{l}-0.352^{* *} \\
(0.073)\end{array}$ & $\begin{array}{l}-0.298 \\
(0.186)\end{array}$ & $\begin{array}{l}-0.238 \\
(0.187)\end{array}$ \\
\hline Fertility in Source Country & $\begin{array}{l}0.146^{* *} \\
(0.019)\end{array}$ & $\begin{array}{l}0.107^{* *} \\
(0.015)\end{array}$ & $\begin{array}{l}-0.008 \\
(0.047)\end{array}$ & $\begin{array}{c}0.001 \\
(0.043)\end{array}$ \\
\hline Real GDP in Source Country (\$US/1000) & $\begin{array}{l}0.022^{* *} \\
(0.002)\end{array}$ & $\begin{array}{l}0.022^{* *} \\
(0.002)\end{array}$ & $\begin{array}{c}0.002 \\
(0.007)\end{array}$ & $\begin{array}{c}0.004 \\
(0.006)\end{array}$ \\
\hline Secondary Enrollment Rate in Source Country & $\begin{array}{l}-0.004^{* *} \\
(0.001)\end{array}$ & $\begin{array}{l}-0.005^{* *} \\
(0.001)\end{array}$ & $\begin{array}{l}-0.002 \\
(0.002)\end{array}$ & $\begin{array}{l}-0.001 \\
(0.002)\end{array}$ \\
\hline Primary Enrollment Rate in Source Country & $\begin{array}{l}0.011^{* *} \\
(0.001)\end{array}$ & $\begin{array}{l}0.012^{* *} \\
(0.001)\end{array}$ & $\begin{array}{c}0.003 \\
(0.002)\end{array}$ & $\begin{array}{c}0.002 \\
(0.002)\end{array}$ \\
\hline $\begin{array}{l}\text { Distance from Source Country to US } \\
\text { (miles/1000) }\end{array}$ & $\begin{array}{c}-0.063^{* *} \\
(0.006)\end{array}$ & $\begin{array}{l}-0.050^{* *} \\
(0.006)\end{array}$ & $\begin{array}{l}-0.021 \\
(0.013)\end{array}$ & $\begin{array}{l}-0.012 \\
(0.024)\end{array}$ \\
\hline English-Speaking Source Country & $\begin{array}{c}0.064 \\
(0.060)\end{array}$ & $\begin{array}{l}0.177^{* *} \\
(0.062)\end{array}$ & $\begin{array}{l}0.297^{*} \\
(0.146)\end{array}$ & $\begin{array}{c}0.127 \\
(0.162)\end{array}$ \\
\hline $\begin{array}{l}\text { English-Official but not English-Speaking } \\
\text { Source Country }\end{array}$ & $\begin{array}{l}0.410^{* *} \\
(0.032)\end{array}$ & $\begin{array}{l}0.298^{* *} \\
(0.022)\end{array}$ & $\begin{array}{l}0.362^{* *} \\
(0.090)\end{array}$ & $\begin{array}{l}0.227+ \\
(0.119)\end{array}$ \\
\hline Married, Spouse Present & $\begin{array}{c}0.027 \\
(0.019)\end{array}$ & $\begin{array}{l}0.103^{* *} \\
(0.015)\end{array}$ & $\begin{array}{l}-0.036 \\
(0.041)\end{array}$ & $\begin{array}{l}-0.008 \\
(0.075)\end{array}$ \\
\hline Years of Schooling Before Migrating & $\begin{array}{l}0.040^{* *} \\
(0.002)\end{array}$ & $\begin{array}{l}0.033^{* *} \\
(0.002)\end{array}$ & $\begin{array}{l}0.038^{* *} \\
(0.007)\end{array}$ & $\begin{array}{l}0.029 * * \\
(0.010)\end{array}$ \\
\hline Years of Schooling in US & $\begin{array}{l}0.060^{* *} \\
(0.010)\end{array}$ & $\begin{array}{l}0.069 * * \\
(0.009)\end{array}$ & $\begin{array}{l}0.132^{* *} \\
(0.017)\end{array}$ & $\begin{array}{l}0.130^{* *} \\
(0.018)\end{array}$ \\
\hline Years Since Migration (YSM) & $\begin{array}{l}0.048^{* *} \\
(0.006)\end{array}$ & $\begin{array}{l}0.033^{* *} \\
(0.005)\end{array}$ & $\begin{array}{l}0.046^{* *} \\
(0.012)\end{array}$ & $\begin{array}{c}0.023 \\
(0.022)\end{array}$ \\
\hline YSM squared (/100) & $\begin{array}{c}-0.142^{* *} \\
(0.018)\end{array}$ & $\begin{array}{l}-0.097^{* *} \\
(0.019)\end{array}$ & $\begin{array}{c}-0.116^{* *} \\
(0.037)\end{array}$ & $\begin{array}{l}-0.052 \\
(0.069)\end{array}$ \\
\hline Inverse Mills Ratio & & & $\begin{array}{l}-0.0729 \\
(0.0812)\end{array}$ & $\begin{array}{l}-0.1596 \\
(0.3792)\end{array}$ \\
\hline $\begin{array}{l}\text { Visa Type Dummies? } \\
\mathrm{N}\end{array}$ & $\begin{array}{c}\text { no } \\
2845\end{array}$ & $\begin{array}{l}\text { yes } \\
2845\end{array}$ & $\begin{array}{c}\text { no } \\
2821\end{array}$ & $\begin{array}{c}\text { yes } \\
2821\end{array}$ \\
\hline
\end{tabular}

$+p<0.10,{ }^{*} p<0.05,{ }^{* *} p<0.01$.

Note: Low work weeks models assign predicted wages to nonworkers based on wage regressions for workers with less than 26 weeks of work. Heckman two step model includes number of own children in the first step. Other controls in the wage regressions include age, age squared, and race/ethnicity. 
Table 6: Effects of Pre-Migration Employment and Source Country Female Labor Supply on Immigrant Women's Log Hourly Earnings

A. Effect of Pre-Migration Work Experience

Low Female Relative Activity Rate HIgh Female Relative Activity Rate

\begin{tabular}{lcccc} 
& \multicolumn{2}{c}{ (25th percentile) } & (75th percentile) \\
\hline OLS & $.089+$ & 0.064 & 0.016 & 0.001 \\
Selection: Low Work Weeks & $.118^{* *}$ & $.091^{* *}$ & 0.003 & 0.010 \\
Selection: Heckman & $.078+$ & 0.037 & 0.009 & -0.018 \\
Visa category variables included? & no & yes & no & yes \\
\hline
\end{tabular}

\section{B. Effect of High vs. Low Female Female Activity Rate Country}

\begin{tabular}{|c|c|c|c|c|}
\hline & \multicolumn{2}{|c|}{ No Pre-Migration Work Experience } & \multicolumn{2}{|c|}{ Worked Before Migration } \\
\hline OLS & 0.116 & $.129+$ & 0.043 & 0.066 \\
\hline Selection: Low Work Weeks & $.353 * *$ & $.204^{* *}$ & $.239 * *$ & $.122 * *$ \\
\hline Selection: Heckman & 0.106 & $.110 *$ & 0.036 & 0.055 \\
\hline Visa category variables included? & no & yes & no & yes \\
\hline
\end{tabular}

$+p<.10 * p<.05 * * p<.01$

Note: Estimates are based on Table 4, columns 5 and 6, and Table 5. Pre-migration hours are set to the mean among those who worked (roughly 2000 hours). The 25th percentile country is Dominican Republic (relative activity rate $=0.47$ ); and the 75th percentile country is Sub-Saharan Africa (relative activity rate=.70). 
Table A1: Means for Recent Immigrants Using the 5\% Sample of the 2000 Census and the 2005 ACS (ages 18-65)

\begin{tabular}{lcccc}
\hline \hline & \multicolumn{2}{c}{2000 Census } & \multicolumn{2}{c}{2005 ACS } \\
Variable & Male & Female & Male & Female \\
\cline { 2 - 5 } Employed & Mean & Mean & Mean & Mean \\
In Labor Force & 0.716 & 0.430 & 0.815 & 0.461 \\
Hours Worked & 0.763 & 0.486 & 0.862 & 0.523 \\
Age & $1,435.7$ & 764.4 & $1,634.4$ & 826.4 \\
Married - Spouse Present & 32.35 & 33.46 & 33.03 & 33.99 \\
Number of Children in Household & 0.404 & 0.588 & 0.411 & 0.595 \\
In(Hourly Earnings) & 0.600 & 0.949 & 0.591 & 0.925 \\
Educational Attainment & 2.39 & 2.23 & 2.42 & 2.29 \\
Latin America and Caribbean & 11.75 & 11.96 & 11.82 & 12.27 \\
Europe and Central Asia & 0.548 & 0.487 & 0.605 & 0.520 \\
South and East Asia & 0.131 & 0.143 & 0.094 & 0.112 \\
Sub-Saharan Africa & 0.212 & 0.264 & 0.195 & 0.258 \\
& 0.038 & 0.038 & 0.044 & 0.043 \\
Sample size & & & & \\
\hline
\end{tabular}

Notes: Sample is restricted to individuals who migrated to the US within the last 5 years, were at least 18 years old when they migrated, are currently not older than 65 , do not have an allocated source country. Means are weighted by the Census provided person weight. Education categories are constructed according to Jaeger (1997). Individuals with any self-employment income, with a selfemployment worker class, or with hourly earnings below $\$ 1 / \mathrm{hr}$ or abor $\$ 250 / \mathrm{hr}$ are excluded from hourly earnings mean. 
Table A2: Selected OLS Results for the Determinants of Annual Work Hours (including zeroes), Adult Immigrant Men

\begin{tabular}{|c|c|c|c|c|c|c|}
\hline & (1) & (2) & (3) & (4) & (5) & (6) \\
\hline Annual Work Hours Before Migrating & $\begin{array}{l}0.108^{* *} \\
(0.024)\end{array}$ & $\begin{array}{l}0.107^{* *} \\
(0.025)\end{array}$ & & $\begin{array}{l}0.107^{* *} \\
(0.025)\end{array}$ & $\begin{array}{l}0.041 \\
(0.087)\end{array}$ & $\begin{array}{l}0.030 \\
(0.088)\end{array}$ \\
\hline Female/Male Activity Ratio in Source Country & & & $\begin{array}{l}67.563 \\
(310.597)\end{array}$ & $\begin{array}{l}186.970 \\
(325.281)\end{array}$ & $\begin{array}{l}5.628 \\
(462.931)\end{array}$ & $\begin{array}{l}-118.371 \\
(372.161)\end{array}$ \\
\hline $\begin{array}{l}\text { Interaction: Annual Work Hours Before } \\
\text { Migrating x Female/Male Activity Ratio }\end{array}$ & & & & & $\begin{array}{l}0.114 \\
(0.127)\end{array}$ & $\begin{array}{l}0.138 \\
(0.128)\end{array}$ \\
\hline Married, Spouse Present & $\begin{array}{l}220.940 * * \\
(60.521)\end{array}$ & $\begin{array}{l}206.756^{* *} \\
(61.746)\end{array}$ & $\begin{array}{l}225.436^{* *} \\
(66.242)\end{array}$ & $\begin{array}{l}206.947^{* *} \\
(61.522)\end{array}$ & $\begin{array}{l}206.728^{* *} \\
(61.621)\end{array}$ & $\begin{array}{l}152.399^{*} \\
(54.953)\end{array}$ \\
\hline Years of Schooling Before Migrating & $\begin{array}{l}24.477^{* *} \\
(6.992)\end{array}$ & $\begin{array}{l}22.000^{* *} \\
(7.696)\end{array}$ & $\begin{array}{l}23.461^{* *} \\
(7.212)\end{array}$ & $\begin{array}{l}22.043^{* *} \\
(7.737)\end{array}$ & $\begin{array}{l}22.114^{* *} \\
(7.676)\end{array}$ & $\begin{array}{l}20.395^{*} \\
(8.326)\end{array}$ \\
\hline Years Since Migration (YSM) & $\begin{array}{l}138.731^{* *} \\
(21.076)\end{array}$ & $\begin{array}{l}137.706^{* *} \\
(21.514)\end{array}$ & $\begin{array}{l}134.050^{* *} \\
(21.057)\end{array}$ & $\begin{array}{l}138.476^{* *} \\
(21.628)\end{array}$ & $\begin{array}{l}138.714^{* *} \\
(21.458)\end{array}$ & $\begin{array}{l}98.596 * * \\
(21.147)\end{array}$ \\
\hline YSM squared (/100) & $\begin{array}{l}-389.934^{* *} \\
(87.036)\end{array}$ & $\begin{array}{l}-394.820^{* *} \\
(91.244)\end{array}$ & $\begin{array}{l}\text { - } 391.416^{*} \\
(92.291)\end{array}$ & $\begin{array}{l}*-397.371^{* *} \\
(92.258)\end{array}$ & $\begin{array}{l}*-398.325^{* *} \\
(91.911)\end{array}$ & $\begin{array}{l}{ }^{*}-262.579 * * \\
(84.413)\end{array}$ \\
\hline Fertility in Source Country & & $\begin{array}{l}82.233^{*} \\
(32.116)\end{array}$ & $\begin{array}{l}96.321+ \\
(48.398)\end{array}$ & $\begin{array}{l}99.771 * \\
(45.452)\end{array}$ & $\begin{array}{l}99.456^{*} \\
(45.798)\end{array}$ & $\begin{array}{l}109.436^{* *} \\
(37.081)\end{array}$ \\
\hline Real GDP in Source Country (\$US/1000) & & $\begin{array}{l}6.077 \\
(7.464)\end{array}$ & $\begin{array}{l}5.891 \\
(7.205)\end{array}$ & $\begin{array}{l}6.964 \\
(7.320)\end{array}$ & $\begin{array}{l}7.017 \\
(7.380)\end{array}$ & $\begin{array}{l}12.193^{*} \\
(4.721)\end{array}$ \\
\hline Secondary Enrollment Rate in Source Country & & $\begin{array}{l}5.424+ \\
(3.014)\end{array}$ & $\begin{array}{l}6.098+ \\
(3.277)\end{array}$ & $\begin{array}{l}5.689+ \\
(3.180)\end{array}$ & $\begin{array}{l}5.622+ \\
(3.156)\end{array}$ & $\begin{array}{l}4.265+ \\
(2.343)\end{array}$ \\
\hline Primary Enrollment Rate in Source Country & & $\begin{array}{l}-1.139 \\
(2.654)\end{array}$ & $\begin{array}{l}-1.347 \\
(2.528)\end{array}$ & $\begin{array}{l}-0.945 \\
(2.664)\end{array}$ & $\begin{array}{l}-0.831 \\
(2.612)\end{array}$ & $\begin{array}{l}-1.353 \\
(1.814)\end{array}$ \\
\hline $\begin{array}{l}\text { Distance from Source Country to US } \\
\text { (miles/1000) }\end{array}$ & & $\begin{array}{l}-2.986 \\
(20.570)\end{array}$ & $\begin{array}{l}-3.622 \\
(21.902)\end{array}$ & $\begin{array}{l}-8.523 \\
(22.671)\end{array}$ & $\begin{array}{l}-8.124 \\
(22.890)\end{array}$ & $\begin{array}{l}-1.884 \\
(17.200)\end{array}$ \\
\hline English-Speaking Source Country & & $\begin{array}{l}92.114 \\
(155.689)\end{array}$ & $\begin{array}{l}61.108 \\
(160.986)\end{array}$ & $\begin{array}{l}56.720 \\
(161.275)\end{array}$ & $\begin{array}{l}62.312 \\
(159.778)\end{array}$ & $\begin{array}{l}53.667 \\
(132.506)\end{array}$ \\
\hline $\begin{array}{l}\text { English-Official but not English-Speaking } \\
\text { Source Country }\end{array}$ & & $\begin{array}{l}34.388 \\
(89.448)\end{array}$ & $\begin{array}{l}35.504 \\
(112.746)\end{array}$ & $\begin{array}{l}54.451 \\
(110.617)\end{array}$ & $\begin{array}{l}52.127 \\
(112.703)\end{array}$ & $\begin{array}{l}-33.772 \\
(67.415)\end{array}$ \\
\hline Family Visa & & & & & & $\begin{array}{l}354.804^{* *} \\
(92.668)\end{array}$ \\
\hline Employment Visa & & & & & & $\begin{array}{l}642.683^{* *} \\
(158.680)\end{array}$ \\
\hline Diversity Visa & & & & & & $\begin{array}{l}-43.706 \\
(85.641)\end{array}$ \\
\hline Refugee Visa & & & & & & $\begin{array}{l}759.675^{* *} \\
(103.749)\end{array}$ \\
\hline Legalization Visa & & & & & & $\begin{array}{l}309.345^{* *} \\
(106.442)\end{array}$ \\
\hline $\mathrm{N}$ & 2622 & 2622 & 2622 & 2622 & 2622 & 2622 \\
\hline Adjusted R squared & 0.222 & 0.226 & 0.214 & 0.226 & 0.226 & 0.257 \\
\hline
\end{tabular}

$+p<0.10, * p<0.05, * * p<0.01$

Note: Sample includes those who migrated at age 18 or later and who are currently no more than 65 years old. Standard errors are clustered at the source country level. Other controls include race/ethnicity, age and age squared. 
Table A3: Selected OLS Results for the Determinants of Annual Work Hours (including zeroes), Married Adult Immigrant Women

\begin{tabular}{|c|c|c|c|c|c|c|}
\hline & $(1)$ & $(2)$ & (3) & (4) & $(5)$ & $(6)$ \\
\hline \multirow[t]{2}{*}{ Annual Work Hours Before Migrating } & $0.098 * *$ & $0.099 * *$ & & $0.095^{* *}$ & $0.222 * *$ & $0.209 * *$ \\
\hline & $(0.014)$ & $(0.013)$ & & $(0.014)$ & $(0.046)$ & $(0.048)$ \\
\hline \multirow[t]{2}{*}{ Female/Male Activity Ratio in Source Country } & & & $840.809 * *$ & $740.053^{*}$ & $963.943 * *$ & $844.443 * *$ \\
\hline & & & $(279.076)$ & $(274.122)$ & $(266.843)$ & $(245.178)$ \\
\hline Interaction: Annual Work Hours Before & & & & & $-0.205^{* *}$ & $-0.185^{*}$ \\
\hline Migrating x Female/Male Activity Ratio & & & & & $(0.069)$ & $(0.073)$ \\
\hline \multirow[t]{2}{*}{ Years of Schooling Before Migrating } & $17.644 * *$ & $12.444^{*}$ & $18.491^{* *}$ & 12.919* & $12.196 *$ & $13.236^{*}$ \\
\hline & $(5.313)$ & $(5.497)$ & $(5.475)$ & $(5.458)$ & $(5.423)$ & (5.709) \\
\hline \multirow[t]{2}{*}{ Years Since Migration (YSM) } & $132.411^{* *}$ & $136.392 * *$ & $137.012^{* *}$ & $138.586 * *$ & $138.252^{* *}$ & $124.237^{* *}$ \\
\hline & $(11.160)$ & $(11.140)$ & $(10.782)$ & $(11.108)$ & $(11.000)$ & $(11.097)$ \\
\hline \multirow[t]{2}{*}{ YSM squared (/100) } & $-368.808^{* *}$ & * $-369.445^{* *}$ & $k-367.670 * *$ & k $-377.845^{* *}$ & $-377.973 * *$ & $-331.496 * *$ \\
\hline & $(51.963)$ & $(47.012)$ & $(54.342)$ & $(51.774)$ & $(50.750)$ & $(48.421)$ \\
\hline \multirow[t]{2}{*}{ Fertility in Source Country } & & -21.650 & 45.394 & 38.536 & 38.141 & 39.600 \\
\hline & & $(46.744)$ & (43.665) & (38.652) & (37.956) & (38.138) \\
\hline \multirow[t]{2}{*}{ Real GDP in Source Country (1995 \$US/1000) } & & -6.258 & -1.655 & -1.436 & -2.224 & 0.417 \\
\hline & & (7.558) & $(6.882)$ & $(6.528)$ & (6.498) & $(5.516)$ \\
\hline \multirow[t]{2}{*}{ Secondary Enrollment Rate in Source Country } & & $4.331+$ & $5.006^{* *}$ & $4.284^{*}$ & $4.175^{*}$ & $4.156^{* *}$ \\
\hline & & $(2.145)$ & $(1.776)$ & $(1.550)$ & $(1.545)$ & $(1.484)$ \\
\hline \multirow[t]{2}{*}{ Primary Enrollment Rate in Source Country } & & -1.636 & -1.127 & -1.520 & -1.720 & 1.110 \\
\hline & & $(2.743)$ & $(2.670)$ & $(2.694)$ & $(2.636)$ & $(2.263)$ \\
\hline Distance from Source Country to US & & $-47.043 *$ & $-65.581 * *$ & $-67.311^{* *}$ & $-68.135^{* *}$ & $-47.299 *$ \\
\hline (miles/1000) & & $(18.422)$ & $(22.921)$ & $(21.442)$ & $(21.237)$ & $(22.492)$ \\
\hline \multirow[t]{2}{*}{ English-Speaking Source Country } & & 91.952 & -81.849 & -47.623 & -44.403 & 9.400 \\
\hline & & $(165.779)$ & $(166.552)$ & $(161.797)$ & $(159.481)$ & $(145.760)$ \\
\hline English-Official but not English-Speaking & & $307.087^{* *}$ & $400.191^{* *}$ & $418.300 * *$ & 411.199** & $362.545^{* *}$ \\
\hline Source Country & & $(90.243)$ & $(90.271)$ & $(89.868)$ & (89.384) & $(76.192)$ \\
\hline \multirow[t]{2}{*}{ Female/Male Activity Ratio in Source Country } & & & $840.809 * *$ & $740.053^{*}$ & $963.943 * *$ & $844.443 * *$ \\
\hline & & & $(279.076)$ & $(274.122)$ & $(266.843)$ & $(245.178)$ \\
\hline \multirow[t]{2}{*}{ Family Visa } & & & & & & 18.761 \\
\hline & & & & & & $(88.411)$ \\
\hline \multirow[t]{2}{*}{ Employment Visa } & & & & & & 175.378 \\
\hline & & & & & & $(138.021)$ \\
\hline \multirow[t]{2}{*}{ Diversity Visa } & & & & & & -47.163 \\
\hline & & & & & & $(120.628)$ \\
\hline \multirow[t]{2}{*}{ Refugee Visa } & & & & & & $405.381^{*}$ \\
\hline & & & & & & $(156.283)$ \\
\hline \multirow[t]{2}{*}{ Legalization Visa } & & & & & & $367.074^{* *}$ \\
\hline & & & & & & $(94.673)$ \\
\hline $\mathrm{N}$ & 2028 & 2028 & 2028 & 2028 & 2028 & 2028 \\
\hline Adjusted R squared & 0.180 & 0.191 & 0.182 & 0.194 & 0.195 & 0.204 \\
\hline
\end{tabular}

$+p<0.10, * p<0.05, * * p<0.01$

Note: Sample includes those who migrated at age 18 or later and who are currently no more than 65 years old. Standard errors are clustered at the source country level. Other controls include race/ethnicity, age and age squared. 
Table A4: Selected OLS Results for the Determinants of Log Hourly Earnings, Married Adult Immigrant Women

\begin{tabular}{|c|c|c|c|c|c|c|}
\hline & (1) & (2) & (3) & (4) & (5) & (6) \\
\hline Worked Before Migrating & $\begin{array}{l}0.065 \\
(0.051)\end{array}$ & $\begin{array}{l}0.074 \\
(0.058)\end{array}$ & & $\begin{array}{l}0.075 \\
(0.058)\end{array}$ & $\begin{array}{l}0.310^{*} \\
(0.144)\end{array}$ & $\begin{array}{l}0.278+ \\
(0.136)\end{array}$ \\
\hline Female/Male Activity Ratio in Source Country & & & $\begin{array}{l}0.389 \\
(0.385)\end{array}$ & $\begin{array}{l}0.393 \\
(0.373)\end{array}$ & $\begin{array}{l}0.636 \\
(0.386)\end{array}$ & $\begin{array}{l}0.678+ \\
(0.359)\end{array}$ \\
\hline $\begin{array}{l}\text { Interaction: Worked Before Migrating x } \\
\text { Female/Male Activity Ratio }\end{array}$ & & & & & $\begin{array}{l}-0.400 \\
(0.241)\end{array}$ & $\begin{array}{l}-0.370 \\
(0.242)\end{array}$ \\
\hline Years of Schooling Before Migrating & $\begin{array}{l}0.045^{* *} \\
(0.008)\end{array}$ & $\begin{array}{l}0.042^{* *} \\
(0.008)\end{array}$ & $\begin{array}{l}0.044^{* *} \\
(0.008)\end{array}$ & $\begin{array}{l}0.042^{* *} \\
(0.008)\end{array}$ & $\begin{array}{l}0.042^{* *} \\
(0.008)\end{array}$ & $\begin{array}{l}0.034^{* *} \\
(0.006)\end{array}$ \\
\hline Years of Schooling in US & $\begin{array}{l}0.131^{* *} \\
(0.025)\end{array}$ & $\begin{array}{l}0.133^{* *} \\
(0.020)\end{array}$ & $\begin{array}{l}0.131^{* *} \\
(0.019)\end{array}$ & $\begin{array}{l}0.134^{* *} \\
(0.020)\end{array}$ & $\begin{array}{l}0.134^{* *} \\
(0.020)\end{array}$ & $\begin{array}{l}0.136^{* *} \\
(0.021)\end{array}$ \\
\hline Years Since Migration (YSM) & $\begin{array}{l}0.047^{*} \\
(0.018)\end{array}$ & $\begin{array}{l}0.054^{* *} \\
(0.015)\end{array}$ & $\begin{array}{l}0.053^{* *} \\
(0.016)\end{array}$ & $\begin{array}{l}0.054^{* *} \\
(0.016)\end{array}$ & $\begin{array}{l}0.054^{* *} \\
(0.015)\end{array}$ & $\begin{array}{l}0.032^{*} \\
(0.013)\end{array}$ \\
\hline YSM squared (/100) & $\begin{array}{l}-0.126 \\
(0.097)\end{array}$ & $\begin{array}{l}-0.156+ \\
(0.083)\end{array}$ & $\begin{array}{l}-0.156+ \\
(0.090)\end{array}$ & $\begin{array}{l}-0.156+ \\
(0.087)\end{array}$ & $\begin{array}{l}-0.151+ \\
(0.085)\end{array}$ & $\begin{array}{l}-0.068 \\
(0.082)\end{array}$ \\
\hline Fertility in Source Country & & $\begin{array}{l}-0.018 \\
(0.063)\end{array}$ & $\begin{array}{l}0.019 \\
(0.070)\end{array}$ & $\begin{array}{l}0.011 \\
(0.070)\end{array}$ & $\begin{array}{l}0.008 \\
(0.068)\end{array}$ & $\begin{array}{l}0.016 \\
(0.067)\end{array}$ \\
\hline Real GDP in Source Country (1995\$US/1000) & & $\begin{array}{l}0.001 \\
(0.008)\end{array}$ & $\begin{array}{l}0.003 \\
(0.008)\end{array}$ & $\begin{array}{l}0.004 \\
(0.008)\end{array}$ & $\begin{array}{l}0.003 \\
(0.008)\end{array}$ & $\begin{array}{l}0.005 \\
(0.006)\end{array}$ \\
\hline Secondary Enrollment Rate in Source Country & & $\begin{array}{l}-0.003 \\
(0.003)\end{array}$ & $\begin{array}{l}-0.002 \\
(0.003)\end{array}$ & $\begin{array}{l}-0.003 \\
(0.003)\end{array}$ & $\begin{array}{l}-0.003 \\
(0.003)\end{array}$ & $\begin{array}{l}-0.002 \\
(0.003)\end{array}$ \\
\hline Primary Enrollment Rate in Source Country & & $\begin{array}{l}0.004 \\
(0.003)\end{array}$ & $\begin{array}{l}0.005 \\
(0.003)\end{array}$ & $\begin{array}{l}0.005 \\
(0.003)\end{array}$ & $\begin{array}{l}0.004 \\
(0.003)\end{array}$ & $\begin{array}{l}0.004 \\
(0.003)\end{array}$ \\
\hline $\begin{array}{l}\text { Distance from Source Country to US } \\
\text { (miles/1000) }\end{array}$ & & $\begin{array}{l}-0.026 \\
(0.018)\end{array}$ & $\begin{array}{l}-0.036+ \\
(0.020)\end{array}$ & $\begin{array}{l}-0.036+ \\
(0.020)\end{array}$ & $\begin{array}{l}-0.037+ \\
(0.019)\end{array}$ & $\begin{array}{l}-0.028 \\
(0.019)\end{array}$ \\
\hline English-Speaking Source Country & & $\begin{array}{l}0.306 \\
(0.183)\end{array}$ & $\begin{array}{l}0.225 \\
(0.193)\end{array}$ & $\begin{array}{l}0.230 \\
(0.189)\end{array}$ & $\begin{array}{l}0.222 \\
(0.187)\end{array}$ & $\begin{array}{l}0.104 \\
(0.214)\end{array}$ \\
\hline $\begin{array}{l}\text { English-Official but not English-Speaking } \\
\text { Source Country }\end{array}$ & & $\begin{array}{l}0.270^{*} \\
(0.125)\end{array}$ & $\begin{array}{l}0.310^{*} \\
(0.113)\end{array}$ & $\begin{array}{l}0.321^{* *} \\
(0.107)\end{array}$ & $\begin{array}{l}0.334^{* *} \\
(0.109)\end{array}$ & $\begin{array}{l}0.251^{*} \\
(0.101)\end{array}$ \\
\hline Family Visa & & & & & & $\begin{array}{l}0.144^{*} \\
(0.052)\end{array}$ \\
\hline Employment Visa & & & & & & $\begin{array}{l}0.608^{* *} \\
(0.105)\end{array}$ \\
\hline Diversity Visa & & & & & & $\begin{array}{l}-0.116 \\
(0.155)\end{array}$ \\
\hline Refugee Visa & & & & & & $\begin{array}{l}0.091 \\
(0.094)\end{array}$ \\
\hline Legalization Visa & & & & & & $\begin{array}{l}0.236^{*} \\
(0.103)\end{array}$ \\
\hline$N$ & 664 & 664 & 664 & 664 & 664 & 664 \\
\hline Adjusted R squared & 0.273 & 0.299 & 0.298 & 0.300 & 0.302 & 0.373 \\
\hline
\end{tabular}

$+\mathrm{p}<0.10, * \mathrm{p}<0.05, * * \mathrm{p}<0.01$

Note: Sample includes those who migrated at age 18 or later and are no more than 65 years old. Standard errors are clustered at the source country level. Sample excludes those enrolled in school. Individuals with hourly earnings less than $\$ 1$ or greater than $\$ 250$ are excluded. Other controls include race/ethnicity, age and age squared. Omitted visa category is "other". Self-employed are excluded. 